This item was submitted to Loughborough's Research Repository by the author.

Items in Figshare are protected by copyright, with all rights reserved, unless otherwise indicated.

\title{
Global geographies of higher education: the perspective of world university rankings
}

PLEASE CITE THE PUBLISHED VERSION

http://dx.doi.org/10.1016/j.geoforum.2012.12.014

PUBLISHER

(C) Elsevier

VERSION

AM (Accepted Manuscript)

LICENCE

CC BY-NC-ND 4.0

\section{REPOSITORY RECORD}

Jons, Heike, and Michael Hoyler. 2019. "Global Geographies of Higher Education: The Perspective of World University Rankings”. figshare. https://hdl.handle.net/2134/12351. 
This item was submitted to Loughborough's Institutional Repository (https://dspace.lboro.ac.uk/) by the author and is made available under the following Creative Commons Licence conditions.

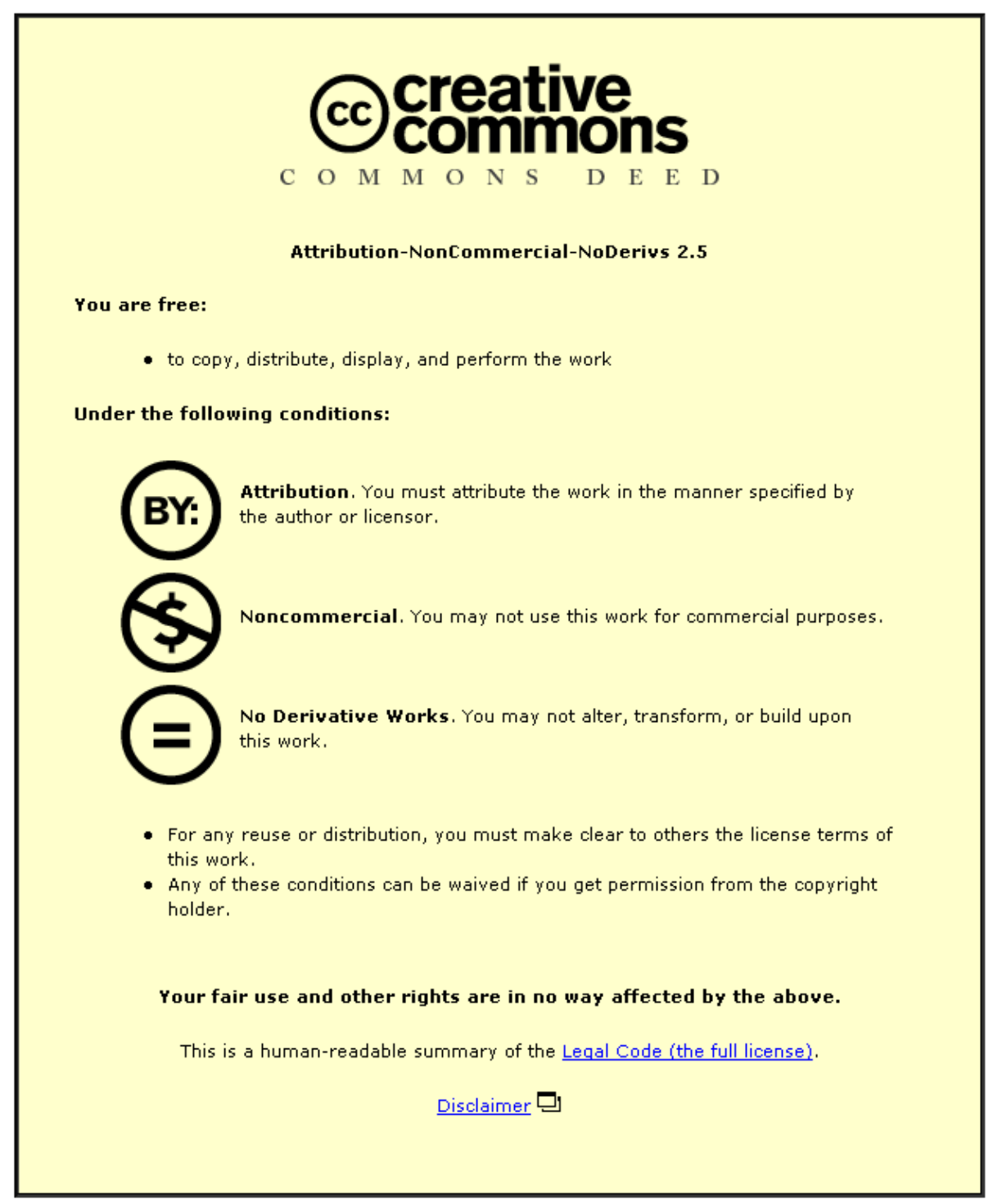

For the full text of this licence, please go to: http://creativecommons.org/licenses/by-nc-nd/2.5/ 


\title{
Global geographies of higher education: the perspective of world university rankings
}

\author{
Heike Jöns* and Michael Hoyler \\ Department of Geography, Loughborough University, Loughborough LE11 3TU, \\ United Kingdom \\ ${ }^{*}$ Corresponding author \\ E-mail: H.Jons@lboro.ac.uk, M.Hoyler@lboro.ac.uk
}

Abstract This paper contributes to emerging debates about uneven global geographies of higher education through a critical analysis of world university rankings. Drawing on recent work in geography, international higher education and bibliometrics, the paper examines two of the major international ranking schemes that have had significant public impact in the context of the on-going neoliberalization of higher education. We argue that the emergence of these global rankings reflects a scalar shift in the geopolitics and geoeconomics of higher education from the national to the global that prioritizes academic practices and discourses conducted in particular places and fields of research. Our analysis illustrates how the substantial variation in ranking criteria produces not only necessarily partial but also very specific global geographies of higher education. In comparison, these reveal a wider tension in the knowledge-based economy between established knowledge centres in Europe and the United States and emerging knowledge hubs in Asia Pacific. An analysis of individual 
ranking criteria, however, suggests that other measures and subject-specific perspectives would produce very different landscapes of higher education.

Keywords world university rankings, knowledge-based economy, higher education, internationalization, globalization, universities 


\section{Introduction}

Geographies of higher education have recently come to the fore of different geographical research agendas as they provide important insights into the formation of a global knowledge economy (Epstein et al., 2007; Hoyler and Jöns, 2008; Olds and Robertson, 2008; Hanson Thiem, 2009; Holloway et al., 2010; Robertson and Olds, 2010). While critical perspectives on the neoliberal corporatization of the university (e.g. Berg and Roche 1997; Castree and Sparke 2000; Mitchell 2008) and studies on transnational academic mobility and business education (e.g. Hall, 2008; Faulconbridge and Hall, 2009; Jöns, 2009, Brooks and Waters 2011) have begun to unravel the complex geographies of higher education from the perspective of students, researchers and academics, there remains a lack of global analyses that focus on changing institutional geographies in higher education and their representations (Holloway and Jöns, 2012; Waters, 2012).

This paper aims to contribute to this emerging field by providing a critical analysis of world university rankings. Since the first of these rankings appeared in 2003, following a decade of increasing internationalization, neoliberalization and marketization of higher education (Teichler, 2004; Lynch, 2006), the annually updated league tables have captured the attention of university managers, employers, policy makers, academics and the wider public (Sadlak and Liu, 2007; Hazelkorn, 2011). Geographers have been vocal in commenting on the newly released data, as documented in several entries on university league tables in the GlobalHigherEd Blog established by geographer Kris Olds and sociologist of education Susan Robertson in September 2007 (Olds and 
Robertson, 2007). What is missing from these important debates are analyses that interrogate more systematically the variety and limitations of the geographies produced by world university rankings.

Drawing upon recent work in geography, international higher education and bibliometrics, we aim to provide such a geographical analysis of world university rankings by exploring how these powerful discourses represent contemporary global higher education to the wider public and what a specifically geographical perspective can contribute to on-going interdisciplinary debates about university league tables. By comparing two of the major international ranking schemes, we develop the argument that because of different types of ranking criteria, inevitable limitations of the underlying data and the rankers' diverse interests, world university rankings always provide highly partial and specific perspectives on the global geographies of higher education. By geographies we mean both the material realities of universities as reflected by the indicators used in the league tables, and the reputational geographies that not only inform their construction but also emerge from the reception of the published rankings. This argument, we suggest, can only be substantiated through a geographical, comparative and disaggregating perspective on different ranking schemes that directs the analytical focus to the level of institutions and thus goes beyond the more common national comparisons of global higher education (e.g. OECD, 2012).

Our starting point is the striking tension between a considerable impact of international ranking schemes on individual and institutional decision-making and a variety of critical voices that question their methodology and value. On 
the one hand, many universities, particularly in Europe and Asia Pacific, have adjusted their strategic plans to become 'world-class' universities as defined by the rankings (IHEP, 2009), thus contributing to what Altbach (2004, p. 5) called the current "age of academic hype in which universities of different kinds in diverse countries claim this exalted status." On the other hand, it has been pointed out that

The influence of league tables is increasing both nationally and internationally, and cannot be ignored despite serious methodological limitations. They are being used for a broader range of purposes than originally intended, and being bestowed with more meaning than the data alone may bear" (HEFCE, 2008, p. 7).

In many ways, this inflated influence of world university rankings mirrors the persuasive discourse about the 'knowledge economy', which Kenway et al. (2006, p. 5) ascribe to "an un-reflexive celebration of the triumphs of contemporary capitalism". Drawing upon this work, we argue that the discourse about world university rankings is similarly "of consequence despite its ambiguity" (Kenway et al., 2006, p. 11) so that university league tables, even if some commentators discount them entirely, need to be scrutinized as important policy drivers of socio-economic change (Espeland and Sauder, 2007; Hazelkorn, 2011).

Methodologically, we chose to analyze the Academic Ranking of World Universities, compiled by Shanghai Jiao Tong University since 2003 (Shanghai 
ranking), and The Times Higher World University Ranking as produced by QS Quacquarelli Symonds Limited from 2004 to 2009 (THE-QS ranking) to examine two highly influential perspectives on global higher education. ${ }^{1}$ Focussing on the years 2006 and 2009, this enables us to examine two established rankings and their changes over time in a rare period without major alterations of the selected indicators and their weightings. As we are interested in comparing geographical clusters of universities and structural variations between two league tables that use very different types of ranking criteria, the same data analysis was conducted for both years. Due to large similarities between the 2006 and 2009 data, we have illustrated our findings mainly but not exclusively with the more recent 2009 data.

The paper is divided into four sections. First, we outline the research contexts that inform current work on geographies of higher education and sketch our conceptual framework. Second, we briefly contextualize the history of world university rankings within recent neoliberal reforms of higher education and critically examine the construction of the Shanghai and THE-QS rankings. Third, we compare the global geographies created in these two world university league tables and discuss how individual ranking criteria represent the university-based knowledge economy. The fourth section concludes by

\footnotetext{
${ }^{1}$ Since 2010, the Times Higher World University Rankings have been generated by Thomson Reuters, known for its research platform ISI Web of Knowledge, which concentrates another aspect of academic performance evaluation in the hands of this New York-based multinational information company. This has entailed a complete overhaul of the methodology employed. QS Quacquarelli continues to publish its own global ranking under the name of QS World University Rankings, so that there are now three major annual rankings in circulation.
} 
discussing wider implications of our findings for conceptual and policy-relevant understandings of the knowledge-based economy.

\section{Geographies of higher education: an emerging field of research}

This paper draws on two main bodies of academic work that usefully inform geographies of higher education. The first comprises geographical studies of universities that have largely neglected world university rankings (for exceptions, see Batty, 2003; Théry, 2009; Robertson and Olds, 2010) but have examined the socio-economic impact, the internationalization/globalization and the neoliberalization of higher education. The second widens this perspective to include interdisciplinary work on international higher education and bibliometrics as the key arenas for academic debates about university rankings. We suggest that analysing world university rankings from a geographical perspective creates important links between these fairly disconnected fields and contributes to both lines of research by introducing debates about world university rankings into geography and a new perspective highlighting the partiality and placespecificity of university league tables into relevant interdisciplinary debates.

\subsection{Geographical perspectives}

Studies investigating geographies of higher education have multiplied since the late 1990s and constitute a heterogeneous but emerging research field within human geography. Recent key themes concerning the production, consumption and governance of higher education include four main lines of inquiry. 
2.1.1 Impact of universities The economic geography of higher education and 'learning regions' focuses on the role of universities for regional economic development in comparison to other geographical scales (e.g. Rutten et al., 2003; Lawton Smith, 2006; Goddard and Vallance, 2011). Fewer studies have looked at the university in its wider social and cultural contexts such as the politics and geographies of honorary degree conferment (Heffernan and Jöns, 2007) and the impact of students on university towns and cities (e.g. Smith and Holt, 2007). These studies highlight the role of universities as key actors in the knowledge economy as they have important economic, social and cultural impacts on their wider region, provide graduates and innovations for the national economy and sustain diverse international linkages (see also Cochrane and Williams, 2012; Meusburger and Schuch, 2012). Recent work on the formation of global educational/knowledge hubs in the world economy has stressed that universities can be regarded as both outcomes and drivers of globalization (Olds, 2007a; Olds and Robertson, 2008; Matthiessen et al., 2010; Lai and Maclean, 2011) so that the geographies of world university rankings need to be positioned within wider socio-economic processes (Robertson and Olds, 2010).

\subsubsection{Transnational mobility Transnational perspectives are also central to} studies that examine the historical geographies of academic mobility and its role for the rise of knowledge centres such as universities (e.g. Charle, 2004a; Jöns, 2008; Taylor et al., 2008; Pietsch, 2010). Similarly, research on the global circulation of academic staff in more recent decades has discussed the extent 
to which this contributes to the formation of transnational knowledge networks (e.g. Ackers, 2008; Jöns, 2009; Leung, 2011). Most studies on global flows in higher education, however, have examined the nature and impact of international student mobility by addressing students' migration decisions, experiences and outcomes; inclusion and exclusion in spaces of education; and transnational educational strategies (e.g. O'Connor, 2005; Findlay et al., 2006, 2012; Hazen and Alberts, 2006; Brooks and Waters, 2011). All of this work helps to conceptualize internationalising universities as potential sites for cumulative processes of transnational mobility and collaboration and, as discussed later in this article, helps to explain why both international students and staff have been used for ranking universities on a global scale.

2.1.3 Academic hegemonies In much of this work on global higher education, distinctive but shifting asymmetries between centres that dominate academic discourse and those with peripheral standing become evident. Within geography, these have been scrutinized in critical interrogations of international publishing spaces (e.g. Paasi, 2005; Aalbers and Rossi, 2007; Bajerski, 2011) and debates about current Anglo-American academic hegemony (e.g. Minca, 2000; Samers and Sidaway, 2000; Garcia-Ramon, 2003; Berg, 2004; Kitchin, 2005; Rodríguez-Pose, 2006; Steinberg, 2009). Paasi (2005), for example, argues that what counts as "international" and "high quality" scholarship is increasingly connected to the journals listed in the Institute of Scientific Information's (ISI) databases provided by Thomson Reuters, which are dominated by Anglo-American periodicals. As world university rankings heavily 
rely upon these data and universities strive to improve their status in such rankings (IHEP, 2009), it can be argued that they reinforce the homogenization of publication practices across the sciences and humanities.

Critical interventions by geographers, however, also remind us that there is no simple binary division between hegemonic Anglophone geography and marginal "other" language geographies but that both can be occupied simultaneously, are co-constitutive through mutual exchanges and shaped by complex power-relations. This is illustrated, for example, by Berg and Kearns (1998, pp. 130-131), who discuss how English native speakers working in New Zealand felt marginalised in comparison to "British and American centres of academic production" but at the same time used theories developed in these centres to "critique hegemonic metropolitan theory". Helms et al. (2005) problematize language as a means of academic communication from their perspective of German-native speakers working at different career stages in British geography. They argue that through the dominance of English as lingua franca, "geography in particular ... will suffer from becoming more and more monolithic", stressing the "rich potential for cross-fertilization of ideas" through publications in non-English language journals, translations of books and articles into English, international editorial boards, international conferences in different language contexts and time spent abroad (Helms et al., 2005, p. 248).

Applying a geographical perspective to world university rankings thus means that we are especially interested in the extent to which Anglo-American hegemony is reproduced by different rankings and individual ranking criteria at various scales and at different times. Our analysis will therefore also draw on 
broader conceptualizations of hegemony that have mainly focused on political, economical and ideological factors in the formation of hegemonic states (Taylor 1996; Arrighi 2010).

2.1.4 Neoliberal corporatization This study also needs to be situated within geographers' critical accounts of the on-going neoliberalization of university research and teaching (e.g., Berg and Roche, 1997; Castree and Sparke, 2000; Mitchell, 2008). Based on these studies, world university rankings can be regarded as the latest manifestation of the neoliberal corporatization of higher education, in which market forces increasingly govern research and teaching, thus leading to "the marketization of education, the commodification of knowledge, and the simple but relentless pressure to produce" (Castree and Sparke, 2000, p. 224). For fee-paying international students, university rankings may serve as a guide of where they can expect to receive 'value for money', while public support for universities is seen as an investment that requires 'accountability' (Robertson and Olds, 2010). The latter has led to a proliferation of audit cultures in higher education that are often informed by the very criteria that constitute world university rankings. These audit cultures have been heavily criticized by geographers for their limited understanding of scholarship and their restriction of academic freedom (e.g., Castree, 2006; Hannah, 2011). Our study will thus pay attention to the extent to which world university rankings represent different types of universities and national systems of higher education. 


\subsection{International higher education}

Within academia, world university rankings have mainly been discussed in the interdisciplinary field of international higher education research and bibliometrics. The majority of commentaries focus on the Shanghai and THEQS rankings, the two most prominent international league tables from 2003 to 2009. The different nature of these two rankings has inspired a number of comparisons (e.g. Dill and Soo, 2005; Usher and Savino, 2006; Taylor and Braddock, 2007), and also produced a range of critical commentaries on their methodologies (e.g. van Raan, 2005; Holmes, 2006; Florian, 2007; Kaur, 2007; Billaut et al., 2010; Bookstein et al., 2010). Among the impact studies of world university rankings (e.g. Marginson and van der Wende, 2007; Hazelkorn, 2011; Rauhvargers, 2011), several reports evaluate international league tables from the perspective of individual countries by analysing the representation of their universities, which highlights the continuing importance of national systems of higher education, particularly through the public funding of universities in most countries (e.g. Liu and Liu, 2005; Marginson, 2007; Yonezawa, 2007; Atkinson, 2008; HEFCE, 2008).

The wider context of these writings is provided by two interrelated debates, namely about processes and practices of internationalization and globalization in higher education (e.g. Knight, 2003; Altbach, 2004; Teichler, 2004; Marginson, 2006; Altbach and Knight, 2007; Leydesdorff and Wagner, 2009a) and the concept of the 'world-class' university (e.g. Altbach and Balán, 2007; Sadlak and Liu, 2007; Deem et al., 2008; Huisman, 2008). Altbach (2003) lists a number of criteria associated with the idea of 'world-class' universities: 
excellence in research; leading academics; academic freedom and an atmosphere of intellectual excitement; internal self-governance; adequate facilities, administrative and technical support; and sufficient funding for research and teaching. Other authors add the presence of bright students, and the enrichment of the cultural, intellectual and public life of wider society (Sadlak and Liu, 2007). However, as Altbach (2003) critically notes, in highly diversified systems of higher education the label 'world-class' is only justified for a very small number of institutions perceived to be at the top internationally. As universities contribute to the creation of new knowledge in often highly specialized ways, it is also impossible to operationalize all these characteristics in a set of globally or even nationally comparable criteria. Acknowledging these difficulties in the context of a diverse and stratified landscape of global higher education (Marginson, 2006), we argue that a differentiated geographical analysis of university rankings can not only reveal their limited and specific perspectives on academic achievement, but also provide important insights into the 'power-geometries' (Massey, 1999) of global higher education.

\section{Construction and reception of world university rankings}

The aim to formally identify the world's 'best' universities in annually published world university league tables marks a new era of globalized higher education at the beginning of the 21st century. This era is characterized by a growing marketization and commodification of higher education driven by the expansion of neoliberal capitalism into core public services (Canaan and Shumar, 2008). Accordingly, Robertson and Olds (2010) suggest to conceptualize world 
university rankings as a project for accountability and transparency; a strategy for generating increasing competition between universities; and a manifestation of globalization processes that reflect and constitute wider social formations. In this section, we consider these wider contexts of international world university rankings, discuss the range of specific performance indicators and critically reflect on their interpretation and impact.

\subsection{History, actors and governance}

International university league tables extend the perspective of national university rankings that have a long-standing tradition in many countries. In the market-orientated system of higher education in the United States, the Carnegie Foundation for the Advancement of Teaching has published a regularly updated classification of colleges and universities since 1973, while the conservative magazine U.S. News and World Report has produced highly influential annual rankings of American colleges and universities since 1983 (Carnegie Foundation, 2010; U.S. News, 2010). Informal rankings existed long before, as expressed in the Ivy League, an athletic conference of eight private universities in the north-eastern United States formed in 1954, which has become emblematic for private elite universities of the highest academic standard.

In recent years, growing interest in the development of higher education in Asia has been a major driving force for the increasing popularity of university rankings. The rapid growth of higher education in China since the 1990s has inspired six different national rankings (Liu and Liu, 2005), while the first transnational university ranking, looking at major Asian universities, was 
produced by the newsmagazine Asiaweek from 1997 to 2000 (Usher and Savino, 2006). The first world university ranking was published by the Center for World-Class Universities (CWCU) at Shanghai Jiao Tong University in 2003 and motivated by a threefold national interest, namely to establish the position of Chinese universities in the world, to measure the gap to the most thriving global research universities, and to identify strategies to develop Chinese higher education institutions into 'world-class' universities (Liu, 2009). Hence, the internationalization of university rankings, while resulting from a growing international outlook on higher education since the late 1990s, was largely driven by national interests and the rankers' desire to define benchmarks for emulating the success of leading research universities in the United States.

In 2004, the Times Higher Education Supplement (now THE), a Londonbased weekly magazine then owned by News International, commissioned the company QS Quacquarelli Symonds Limited to compile an alternative international ranking that has since been published annually. Since 2008, the THE-QS data have been used by U.S. News and World Report for their new annual World's Best Colleges and Universities Rankings (U.S. News, 2010). It can thus be argued that U.S. News' efforts to extend their analytical gaze from the national to the global level confirms a growing interest in worldwide comparisons of universities and the emergence of an increasingly global education market. In 2010, THE severed its ties with QS Quacquarelli and commissioned the Thomson Reuters corporation with the compilation of its ranking, while QS Quacquarelli has continued to publish its own annual ranking. 
Responding to a wide range of methodological criticism levelled at both initial rankings, alternative world university rankings, such as the Leiden ranking (Moed, 2006), have been developed. In 2010, the OECD launched an international university ranking initiative to focus on learning outcomes and transferable skills (Olds, 2007b; Morgan, 2010), and the European Commission appointed the multinational CHERPA research network to design a multidimensional world university ranking, which published a feasibility study in 2011 (van Vught and Ziegele, 2011). The involvement of these supranational actors in the construction of global university league tables points to a diversification of agents that is based on varying interests of the different stakeholders.

The on-going diversification has helped to put world university rankings into perspective but has also raised questions about their governance (Enserink, 2007). In 2004, the UNESCO European Centre for Higher Education (UNESCO-CEPES) in Bucharest and the Institute for Higher Education Policy in Washington, DC founded the International Rankings Expert Group (IREG) to assure 'good ranking practice' and thus a higher credibility of university league tables (IREG, 2006). Based on the 'Berlin Principles on Ranking of Higher Education Institutions', formulated in 2006, IREG aims to approve rankings as 'IREG Recognized' (Sadlak and Liu, 2007). However, as this self-declared body of authority includes members that are producing the Shanghai, U.S. News and other rankings, Olds (2008) has rightly questioned its legitimacy. 


\section{2 'Objective' and 'subjective' indicators}

The annually published world university league tables are based on a range of specific performance indicators that have been subject to intense debate. Based on a comparison of 19 rankings, Usher and Savino $(2006$, p. 3) found that the "world's main ranking systems bear little if any relationship to one another, using very different indicators and weightings to arrive at a measure of quality". The most contested issue has been the use of so-called 'objective' and 'subjective' ranking criteria. The former comprise bibliometric and other statistical data on journal articles, citations, research funding and staff/student ratios, while the latter are derived from surveys among peers, employers, graduates, students and others. The main difference between the Shanghai and THE-QS rankings lies in their different emphasis on 'objective' and 'subjective' indicators of academic performance.

3.2.1 The Shanghai and THE-QS rankings The Shanghai ranking publishes a list of 500 universities out of c. 15,000 higher education institutions worldwide (IAU, 2010). More than 2,000 universities are scanned and over 1,000 are ranked (Liu and Cheng, 2005). The ranking is based on six 'objective' indicators that aim to measure quality of research and education. A university's final ranking position is determined by adding the weighted scores of individual indicators (Table 1).

The Shanghai ranking is most often criticized for its concentration on research performance ( $90 \%$ of the total score) at the expense of learning and teaching; for the significant consideration of the history of universities; and for 
its focus on the natural, technical and social sciences at the expense of the arts and humanities (Taylor and Braddock, 2007). 'Quality of Education' is measured by the number of alumni who received Nobel Prizes and - in mathematics Fields Medals. In the 2009 ranking, the data for the period 1901-2008 were weighted by decades from 10\% (1901-1910) to 100\% (after 1991), thus favouring institutions with a long history of academic achievement. In the case of the two follow-up institutions of the former University of Berlin, the Freie Universität (FU) and the Humboldt Universität $(\mathrm{HU})$, this led to the bizarre situation that their unresolved quarrel about claiming the Nobel Prizes of Albert Einstein and others has resulted in their removal from the Shanghai ranking since 2007 (Enserink, 2007).

[Please insert Table 1 about here]

The THE-QS ranking lists 500 to 600 universities out of which the Top 200 are widely published. The ranking is also based on six indicators but these differ from the Shanghai criteria by including both 'objective' and 'subjective' indicators of academic performance: $40 \%$ of the total score are based on bibliometric measures; $50 \%$ stem from surveys among academic peers and graduate recruiters; and the remaining $10 \%$ consider the international diversity of universities (Table 1$)^{2}$ This ranking was initially mostly criticized for the low response rates of the review surveys and for a general lack of methodological

2 From 2010, the QS World University Rankings have continued this methodology (http://www.topuniversities.com/university-rankings/world-university-rankings); the new THE World University Rankings place less emphasis on reputation (33\% in 2011-12; http://www.timeshighereducation.co.uk/world-university-rankings/; both accessed 08.10.11). 
transparency. Substantial revisions of the methodology have also generated very different THE-QS rankings, which complicate comparisons over time (Kaur, 2007; Aguillo et al., 2010) and prompted us to compare the last 4 years of the Times Higher ranking compiled by QS Quacquarelli.

3.2.2 Critical comparison Opinions about the usefulness of the criteria that constitute the discussed world university rankings diverge. On the one hand, the relatively strong reliance of the THE-QS ranking on review surveys has led some commentators to favour the Shanghai ranking due to its focus on what they regard as "genuine criteria of excellence" (Taylor and Braddock, 2007, p. 247). By contending that the judgement of peers would "be influenced by their own prejudices, loyalties and other positive and negative feelings arising from personal experience" (Taylor and Braddock, 2007, p. 248), these authors are evidently opposed to the widespread credo that peer review indicators can represent an important dimension of everyday evaluations, practices and perceptions in higher education, particularly as "reputation is precisely what universities want in order to generate virtuous circles of investment and accomplishment" (Atkinson 2008, p. 67). On the other hand, bibliometric researchers have criticized the Shanghai rankers for the selection and weighting of their ranking criteria (Billaut et al., 2010; van Raan, 2005) and for inconsistencies in their methodology as these researchers failed to reproduce the Shanghai ranking despite using the same publicly available data sources (Florian, 2007; Kivinen and Hedman, 2008). 
Apart from such opposing views and related debates about the transparency and quality of different ranking methodologies, we wish to stress that any statistical data for measuring academic performance are problematic constructions. Not only does human judgement interfere when decisions are made about which journals enter the respective database but publication and citation counts are biased towards English-language journals, neglecting academic work published elsewhere (Paasi, 2005; van Raan et al., 2011). Citation indexes also tend to ignore subject-specific publication cultures, including the role of individual and collective authorship (Jöns, 2007). The Shanghai group itself pointed to problems in the construction of their quantitative indicators, including the treatment of hospitals and multi-campus universities; different names for one and the same institution; and the merging and splitting of universities (Liu and Cheng, 2005).

In this paper, we take up Haraway's (1988) critique of traditional notions of scientific objectivity when arguing that all rankings of academic excellence are problematic, no matter what type of criteria they employ. This is because they always produce limited representations of higher education that are shaped by specific politics of inclusion and exclusion. A different emphasis on 'objective' and 'subjective' ranking criteria thus does not allow for a normative differentiation of 'good' and 'bad' rankings but rather suggests the need to closely examine the methodology and outcome of each ranking in terms of the dimensions of higher education that are represented and thus prioritized. 


\section{Global geographies of higher education}

From a geographical perspective, three key questions emerge from the identified methodological differences between the Shanghai and THE-QS rankings: What types of universities feature in both rankings and where are these institutions located? Which clusters of 'world-class' universities can be identified? And how do individual ranking criteria represent the university-based knowledge economy? By investigating these key questions, this section substantiates our argument that world university rankings always present highly partial perspectives on global higher education, even if they identify a few common clusters of academic excellence.

Aiming to put this type of knowledge production through world university rankings in its place (Livingstone, 2003), we apply a comparative, geographical and disaggregating perspective to the ranking data. Rather than comparing the ranking positions of individual universities that have attracted much of the public attention, we analyze tiers of ranked universities at the level of countries and cities/places for the years 2006 and 2009. We therefore do not focus on the more questionable short-term fluctuations in ranks of individual universities, but on the more stable tiers and structural variations between different types of rankings and their constitutive criteria. The first and third sections look at the Top 200 universities in each ranking; the second section compares the Top 500 institutions. The publicly available data were downloaded from the websites of CWCU at Shanghai Jiao Tong University, the Times Higher Education magazine, and QS Quacquarelli Symonds Ltd.; locational information was added via an internet search. 


\subsection{Established and emerging 'world-class' universities}

First, we wish to establish what geographies of global higher education the two rankings produce. Comparing the Top 200 universities in both rankings for 2009 shows an overlap of 138 universities (Table 2). These universities form four regional clusters in the core of the world economy, namely in North America, Europe, East Asia and Australia (Figure 1a). South America and Africa are basically off this map, confirming wider economic disparities between the global North and South as well as the underrepresentation of non-Anglophone universities in rankings designed to account for research excellence according to Anglo-American academic standards. Those 62 universities that are only listed in the Top 200 of the Shanghai ranking cluster in North America and Europe (Figure 1b), while the 62 universities only represented in the Top 200 of the THE-QS ranking are mainly located in Europe, East and South East Asia, Australia and New Zealand (Figure 1c). The different types of indicators thus produce not only diverse rankings but also varying geographies: The Shanghai ranking, with its stress on 'objective' indicators of scientific achievement and the path dependency of academic excellence, centres on the United States and Europe, while the THE-QS ranking, incorporating 'subjective' indicators of academic performance and internationalization measures, produces a geography that emphasizes Europe and Asia Pacific.

[Please insert Table 2 about here] 
The fact that the Asian-based ranking looks to the West makes quite clear which type of 'world-class' universities the Chinese rankers aspire to compete with, while the European-based ranking's gaze towards the East captures the dynamism of some of the emerging research universities in Asia Pacific. This wider region provides a lucrative market for British and other European universities in terms of exporting educational programmes and recruiting international students (Halpin and Buckley, 2004). The argument that Asia Pacific encompasses some highly dynamic places in the contemporary landscape of global higher education is supported by the worldwide output of research papers in the sciences and engineering. Between 1996-2000 and 2001-2005, this output increased by more than $10 \%$, while among the nine countries with the most productive scientists, the growth of research output was highest in China, India and Australia (Adams et al., 2007, p. 10).

[Please insert Figure 1 about here]

Europe hosts a large number of universities that score well in both rankings, which indicates the region's central status in global higher education and research. Scientists in the 27 member states of the European Union in fact account for a higher share of publications listed in the Science Citation Index (2008: 35\%) than US scientists (28\%). Leydesdorff and Wagner (2009b, p. 356) suggested that "China's contribution to world science could be as large as that of the USA by 2014". Comparing the share of Top 200 and Top 500 universities in selected countries for both rankings in 2006 and 2009, however, suggests a 
note of caution towards predicting such rapid changes in scientific predominance. US research universities still account for over $40 \%$ of the Top 200 and Top 500 in the Shanghai ranking, while no Chinese university appeared in the Top 200 in 2009. Even in the THE-QS ranking, in which US universities reach a share of $20-30 \%$, Chinese universities account for only 2$3 \%$ of higher education institutions in both tiers and years. Interestingly, the data reveal divergent trends in the upper and lower tiers of the Shanghai ranking as the domination of US and UK universities in the Top 200 increased from 2006 to 2009, while a gradual decentralization can be observed in the Top 500 due to the recent entry of universities from countries such as China, Taiwan, Australia and Brazil (Table 3).

[Please insert Table 3 about here]

The difference in emphasis between the two rankings means that universities aiming to climb up the ranks have to apply different strategies in regard to each ranking. By considering the history of universities, the Shanghai ranking clearly disadvantages new universities and favours institutions such as the University of Munich, in 2009 the top ranked German university (at 55; THE-QS: 98), with a particularly high number of alumni who received Nobel Prizes in the first half of the 20th century (16 from 1901 to 1950; ten since 1951). Due to the importance of peer review and international outlook, higher positions are easier to achieve in the THE-QS ranking through marketing among peers and investment in internationalization strategies. 
It is this difference in emphasis on research performance and research reputation that distinguishes both rankings more than anything else: established universities and scientific stars are favoured in one, emerging universities and international diversity in the other. Our geographical and comparative analysis thus suggests that both types of indicators are partial and represent very different aspects of global higher education. Due to the diverging time-reference of the data, including the whole 20th century in one and not more than 5 years in the other ranking, these aspects show distinct geographies that are closely linked to the historical formation of knowledge nodes and networks.

\subsection{Clusters of 'world-class' universities}

The rankings' distinct geographies are expressed in specific clusters of 'worldclass' universities that emerge on a range of geographical scales. Mapping the locations of the Top 500 universities by five tiers of 100 institutions confirms striking disparities between the global North and South (Figure 2). In addition to the four major regional clusters in North America, Europe, East Asia and Australia there are also two minor clusters in South America and South Africa but large parts of these continents are without any university that scores on the main performance indicators as defined in the rankings. This reflects both the uneven representation of different cultural contexts in world university rankings and the significant influence of deep-seated asymmetries in the global economy on global higher education. Sadlak and Liu (2007, p. 20), for example, argue that the concentration of the Shanghai Top 100 universities in the core zones of the world economy is closely linked to "the threshold costs of supporting such 
establishments", which "is around 1.5 billion US dollars per year and 2 billion US dollars in cases where the university also includes a medical school/faculty and appropriate clinical hospital" (see also Altbach, 2003). League tables therefore also represent significant material inequalities between universities, which are linked to long-term accumulation processes in the global North.

[Please insert Figure 2 about here]

Within the United States, clusters of Top 100 universities concentrate in the established economic centres in the northeast, the middle west and the west coast, while the locations of Top 100 universities in Europe are characterized by a centre-periphery structure that reflects historical patterns in the establishment of the modern research university (Figure 2; Taylor et al., 2008). Accordingly, the leading European universities cluster in the south of England, in and around Paris, in southwest Germany and in northern Switzerland, while Spain, the south of Italy and east central Europe accommodate universities mainly ranked between 300 and 500. Both rankings represent the same regional clusters in the United States and Europe among their Top 500 universities, which confirms the important status of long established research universities, but the THE-QS ranking, due to its focus on the previous 5 years, covers a much wider range of universities in Asia Pacific.

The existence of an Anglo-American academic hegemony in the early 21 st century is evident in the strong representation of US and British universities in the top tiers of the Shanghai and THE-QS rankings. Out of the 
100 highest ranked institutions in 2009, the majority are located within the United States (Shanghai: 55 institutions; THE-QS: 32), followed by the United Kingdom (Shanghai: 11 institutions; THE-QS: 18). In the United States, this hegemony is based to a significant degree on a number of wealthy private research universities that benefit from both alumni donations favoured by the tax system and high tuition fees (Altbach, 2003). US authors are also favoured by publication and citation counts as "the peer review system is dominated by people accustomed to both the language and methodology of US scholars" (Altbach, 2003, pp. 10-11), which can even create feelings of marginalization for authors based in other parts of Anglophone academia (Berg and Kearns, 1998).

A comparison of the number of ranked universities with all doctorategranting universities in 15 selected countries shows that Switzerland, the Netherlands and Sweden are particularly well represented, which can be explained by their widespread adoption of Anglo-American academic practices such as English-language courses (Table 4). They are followed by Australian, German and Canadian universities with at least one third of their universities listed in the Top 500 of both rankings. This reflects the rankings' bias towards Anglophone sciences and, in the case of Germany, underlines the high scientific productivity and international integration of its public universities. Based on state-sponsored programmes for transnational academic mobility that have facilitated the formation of transnational knowledge networks since the 1950s, Germany has risen to become the most important source country of international co-authors for US scientists and engineers in the early 21st 
century (Jöns, 2009), which has contributed to the relatively favourable representation of German universities in both rankings.

The poor representation of France's public universities in both rankings motivated the French government to issue a new law in August 2007 granting more autonomy to these institutions (Enserink, 2007). This example of a neoliberal university reform inspired by world university rankings consequently met opposition from unions and academics who feared for academic freedom and higher education's public service ethos (Marshall, 2007). Illustrating the significant impact of world university rankings on higher education policies, the French case also shows that the reception of global university league tables similar to their construction - has been strongly framed by national interests.

[Please insert Table 4 about here]

At a time of increasing institutional autonomy and worldwide competition of universities, hierarchical relations between national systems of higher education are being transformed through various forms of transnational networks and flows of people, knowledge and resources that increasingly complicate the identification of core, semi-peripheral and peripheral regions in the knowledge economy. Comparing clusters of Top 500 universities below the national level, for example, reveals that among the Top 10 cities in both rankings, global cities in the Americas (6), in Asia Pacific (5) and in Europe (4) are fairly balanced. The leading world cities London, Paris, Tokyo and New York emerge as those with the highest numbers of ranked institutions in both league tables and are 
therefore also central hubs in global higher education, even if not necessarily the places with the highest ranked institutions overall (Table 5).

[Please insert Table 5 about here]

\subsection{Comparing individual ranking criteria}

The different geographies of higher education that emerge from the Shanghai and THE-QS rankings are confirmed by an examination of individual ranking criteria. The focus of this final section is on how indicators that aim to compare universities' reputation, citation frequency and degree of internationalization represent wider networks and linkages within global higher education.

4.3.1 Reputation and Citation Comparing the academic reputation of the Top 200 THE-QS universities among over 9000 reviewers from five main subject areas with their research performance reveals a considerable gap between the peer review and the citations per faculty scores for universities in Mexico, Russia, East and South East Asia, Australia and New Zealand. While the scientific performance at many universities in these countries seems to be highly valued within the wider region, articles produced for journals listed in the citation indexes are not as frequently cited internationally as work produced in US and European universities. This may partly result from the limited scope and quality of the citation data but can also be attributed to different degrees of integration into scientific citation circuits. We suggest that the discrepancy between a high peer review score and a modest citations per faculty score in 
Asian Pacific universities reveals their status as relatively new actors in the international research community dominated by the Anglophone sciences.

A similar relationship emerges for the scores of published scientific articles and highly cited researchers in the Top 200 universities of the Shanghai ranking: Highly cited researchers are concentrated in a much smaller number of universities. The discrepancy between scores is highest in East Asian universities, where academics have started to publish frequently in indexed journals but not many have yet emerged as highly cited scientific stars (Figure 3). From 2006 to 2009, the Top 500 universities in twelve countries improved on average their scientific output and their share of highly cited researchers. This includes six members of the Commonwealth of Nations (United Kingdom, Canada, Australia, New Zealand, India and South Africa) and the United States, thus reinforcing Anglo-American hegemony to some extent (the others are Norway, Denmark, Switzerland, Italy and Greece).

Examining individual ranking indicators of reputation and citation thus helps to provide insights into broader developments in global higher education such as the existence of an Anglo-American hegemony that might soon be challenged by emerging research universities in Asia Pacific. However, these representations are necessarily partial as they are based on indicators meeting the standards of Anglo-American research practices and discourses in the laboratory-based natural and technical sciences, and to a lesser extent in the social sciences. Paasi's (2005, p. 781) world maps on international publishing spaces clearly show that citation indexes are not able to capture the complexity, place- and language-specificity of scholarship in the arts and humanities, while 
areas such as Latin America, in which other languages than English dominate science and scholarship more generally, are also strongly underrepresented across all disciplines. By focussing only on research practices conducted in particular disciplines and places, world university rankings thus convey a fairly limited understanding of science and scholarship that resonates with wider critiques of neoliberal audit cultures in higher education (e.g., Strathern, 2000; Castree, 2006). All in all, world university rankings represent best those investment-intensive areas of the technosciences that facilitated American hegemony in the second half of the 20th century and that China is now trying to emulate.

[Please insert Figure 3 about here]

4.3.2 Internationalization The growing interest of governments, universities and academics to position themselves globally have made internationalization strategies a priority of many higher education agendas. These strategies include international exchanges, research collaborations, the internationalization of the curriculum, the attraction of promising young scholars and international star scientists, the establishment of branch campuses abroad and the formation of international research and teaching consortia (Knight, 2003). The increasing significance of the international dimension of higher education is reflected in the THE-QS ranking through the inclusion of scores for international students and faculty. 
Out of 3 million international students worldwide, nearly $50 \%$ study in only four countries, namely the United States (19.7\%), the United Kingdom (11.6\%), Germany (8.6\%) and France (8.2\%) (OECD, 2009). While the United States attracts by far the most international students, their share of the total student body is only $3.4 \%$. The highest proportion of international students is to be found in Australia (19.5\%), followed by the United Kingdom, Switzerland, New Zealand and Austria (OECD, 2009). Universities in South Korea, New Zealand, Australia and Japan have considerably raised their market share of international students from 2000 to 2007, thus indicating a wider shift of student flows towards Asia Pacific.

The high shares of international students in Australia are confirmed in the THE-QS ranking 2009 as eight out of nine Australian universities in the Top 200 are among the 50 most international institutions on this measure (Figure 4). Their emphasis on attracting international students, pursued to a similar extent in Singapore, Hong Kong and New Zealand can be interpreted as a distinct strategy to become being "viewed as 'part of the core"' (Paasi, 2005, p. 776). This is because international students not only generate important income through student fees but are potential future academics and professionals. Whether they stay in the country of their studies, return to their country of origin or move to a third country, they are likely to establish transnational linkages and act as multipliers of international relations in their subsequent careers (Saxenian, 2006). A high share of international students thus indicates dynamic processes with potential future significance for the economy and wider society. As the number of international students worldwide has been estimated to 
increase threefold from 2003 to 2025 (Böhm, 2003), international student flows can be expected to reinforce the central status of some of the existing global knowledge hubs and to contribute to the formation of new central nodes in the world economy.

[Please insert Figure 4 about here]

Another strategy of internationalization in higher education has long been the transnational exchange of academic staff, whether this relates to temporary stays or more permanent arrangements. Both visiting academics and foreignborn/foreign-educated academics can provide international views and experiences to the majority of students that do not themselves study abroad. Universities in Singapore, Hong Kong, Taiwan, Australia and New Zealand stand out by their recruitment of international faculty, which is sometimes but not always related to their large number of international students as an important staffing source. The recruitment of international faculty also helps to raise the global visibility of universities as international scientists and scholars bring their academic expertise and contacts to the new institutions. The recruitment of international faculty has therefore been identified by several younger academic institutions as an important strategy for raising their position in world university rankings (see also Universities UK, 2007).

By integrating internationalization in its methodology, the THE-QS ranking thus considers a set of indicators that document both a current initiative for ensuring international competitiveness and potential future dynamic changes 
in academic and professional networks. However, the use of international outlook indicators is not uncontested. Ackers, for example, agrees that academic mobility "is one means of achieving international research collaboration and knowledge transfer" (2008, p. 432) but also criticizes the tendency to use "the concept as a proxy for internationalization, excellence and competitiveness" (2008, p. 413) because individual mobility experiences vary considerably and are not always a marker of academic excellence.

\section{Conclusion}

This paper contributes to wider debates about geographies of higher education and the formation of a global knowledge economy through a detailed study of world university rankings (Epstein et al., 2007; Holloway and Jöns, 2012). Based on a comparative, geographical and disaggregating perspective on two prominent league tables, we have provided a comprehensive analysis of the global geographies that these rankings produce. Our findings can be summarized in five main points.

First, the production of world university rankings in the early 21 st century has been shaped by a new era of globalization and neoliberalization in higher education. Initially, it was driven by the distinct national interest of China to create benchmarks for developing research universities similarly to those in the United States that have dominated global science since the mid-20th century. According to Taylor (1996), such emulation of key institutions and practices in the world economy's most recent hegemonic centre is an important requirement for hegemonic rivals to emerge. Within higher education, this process has its 
historical precedent in the late 19th century, when existing and newly founded US universities were modelled after the then leading German research universities (Charle, 2004b).

Second, the highly uneven geographies of higher education that emerge from the analysis mark particular nodes in the global circulation of knowledge and expertise, namely those that conform best to the Anglo-American publication culture in the highly expensive technosciences that facilitated American hegemony in the second half of the 20th century and are seen as drivers of economic growth (Kenway et al., 2004; Paasi, 2005). The resulting geographies display striking disparities between the global North and South as well as between the economically prospering regions in North America, Europe, East Asia and Australia and large parts of South America, Africa and Asia that are either economically disadvantaged and/or dominated by other languages than English. An examination of different geographical scales and individual ranking criteria provided further evidence that both league tables produce highly partial geographies of global higher education that are to some extent reflective of wider economic and socio-cultural inequalities but also convey a very narrow view of science and scholarship, namely one that can be captured by Anglophone neoliberal audit cultures (e.g., Castree, 2006).

Third, the two main methodological differences between the Shanghai and the THE-QS ranking data are their differing emphasis on research performance and research reputation and their diverging time-reference, comprising no less than the whole 20th century in one and only the past 5 years in the other ranking. Therefore, both rankings also represent very different 
aspects of the contemporary global higher education landscape as captured by Anglo-American research practices and discourses: established universities fare better in the Shanghai ranking, while emerging universities feature more prominently in the THE-QS ranking.

Fourth, the different types of indicators used in the Shanghai and THEQS rankings produce distinctive geographies of global higher education that reveal a wider tension in the knowledge-based economy between established knowledge centres in Europe and the United States and emerging knowledge hubs in Asia Pacific. In particular, the growth of the Chinese economy during the past decade is closely related to the aspiration of Chinese universities to perform as well as the leading US research universities and expressed in an exponential rise of scientific productivity in China. This raises the question whether we currently witness a potential long-term shift in academic hegemony from Anglo-America to Asia that reflects and contributes to wider transformations in the global economy (Altbach, 2010, Levin, 2010, Robertson and Olds, 2010).

Fifth, the emergence of new knowledge hubs and networks in Asia Pacific and elsewhere also indicates a growing significance of transnational processes in global higher education. Conceptually, our study thus implies that Anglo-American academic hegemony may be challenged by two competing developments: a potential shift to East Asia and a proliferation of different tiers of knowledge hubs across the world. These two processes are currently leading to dynamic changes in the global knowledge economy and provide an important 
context in which the production, circulation and interpretation of world university rankings need to be situated.

In conclusion, we argue that a geographical analysis of world university rankings that considers different rankings and scrutinizes the ranking data on a variety of scales, such as tiers of institutions, cities and countries, adds three important dimensions to interdisciplinary debates about university league tables. First, it illustrates the partiality of this discourse through its focus on one segment of global higher education dominated by Anglo-American research practices in the natural and technical sciences. Second, it outlines the even more specific perspectives of different rankings on these partial representations. In our view, this further undermines the authority that public discourse tends to grant world university rankings and confirms that any representations of academic performance provide necessarily limited accounts of material and reputational geographies. Finally, our comparative, geographical and disaggregating analysis has revealed wider structures and dynamics within the dominant sphere of global higher education, but it has also stressed that other measures and subject-specific perspectives would produce very different geographies.

\section{Acknowledgments}

We are grateful to Sarah Holloway, Pádraig Carmody and the anonymous referees for their constructive comments on earlier versions of this article and to Mark Szegner and Raf Verbruggen for supporting the data analysis. 


\section{References}

Aalbers, M.B., Rossi, U., 2007. A coming community: young geographers coping with multi-tier spaces of academic publishing across Europe. Social and Cultural Geography 8 (2), 283-302.

Ackers, L., 2008. Internationalisation, mobility and metrics: a new form of indirect discrimination? Minerva 46 (4), 411-435.

Adams, J., Gurney, K., Marshall, S., 2007. Patterns of International Collaboration for the UK and Leading Partners. Evidence Ltd., Leeds.

Aguillo, I.F., Bar-llan, J., Levene, M., Priego, J.L.O., 2010. Comparing university rankings. Scientometrics 85 (1), 243-256.

Altbach, P.G., 2003. The costs and benefits of world-class universities International Higher Education (33), 5-8. http://www.bc.edu/research/cihe/ihe.html (accessed 08.10.11).

Altbach, P.G., 2004. Globalisation and the university: myths and realities in an unequal world. Tertiary Education and Management 10 (1), 3-25.

Altbach, P.G., 2010. The Asian higher education century? International Higher Education (59), 3-5. http://www.bc.edu/research/cihe/ihe.html (accessed 08.10.11)

Altbach, P.G., Balán, J. (Eds.), 2007. World Class Worldwide: Transforming Research Universities in Asia and Latin America. The Johns Hopkins University Press, Baltimore.

Altbach, P.G., Knight, J., 2007. The internationalization of higher education: motivations and realities. Journal of Studies in International Education 11 83-4), 290-305. 
Arrighi, G., 2010. The Long Twentieth Century: Money, Power and the Origins of Our Times, second new and updated ed., Verso, London.

Atkinson, M., 2008. Should Canada create elite universities? Policy Options March 2008, 65-70.

Bajerski, A., 2011. The role of French, German and Spanish journals in scientific communication in international geography. Area 43 (3), 305-313.

Batty, M., 2003. World class universities, world class research: what does it all mean? Environment and Planning B: Planning and Design 30, 1-2.

Berg, L.D., 2004. Scaling knowledge: towards a critical geography of critical geographies. Geoforum 35 (5), 553-558.

Berg, L.D., Kearns, R.A., 1998. America unlimited. Environment and Planning D: Society and Space 16 (2), 128-132.

Berg, L.D., Roche, M.M., 1997. Market metaphors, neo-liberalism and the construction of academic landscapes in Aotearoa/New Zealand. Journal of Geography in Higher Education 21 (2), 147-161.

Billaut, J.-C., Bouyssou, D., Vincke, P., 2010. Should you believe in the Shanghai ranking? An MCDM view. Scientometrics 84 (1), 237-263.

Böhm, A., 2003. Global Student Mobility 2025: Analysis of Global Competition and Market Share. IDP Education Australia, Sydney.

Bookstein, F.L., Seidler, H., Fieder, M., Winckler, G., 2010. Too much noise in the Times Higher Education rankings. Scientometrics 85 (1), 295-299.

Brooks, R., Waters, J., 2011. Student Mobilities, Migration and the Internationalization of Higher Education. Palgrave Macmillan, Basingstoke. 
Canaan, J.E., Shumar, W. (Eds.), 2008. Structure and Agency in the Neoliberal University. Taylor and Francis, New York.

Carnegie Foundation (Ed.), 2010. The Carnegie Classification of Institutions of Higher Education http://classifications.carnegiefoundation.org/ (accessed 08.10.11).

Castree, N., 2006. Research assessment and the production of geographical knowledge. Progress in Human Geography 30 (6), 747-782.

Castree, N, Sparke, M., 2000. Professional geography and the corporatization of the university: experiences, evaluations, and engagements. Antipode 32 (2), 222-229.

Charle, C., 2004a. The intellectual networks of two leading universities: Paris and Berlin, 1890-1930. In: Charle, C., Schriewer, J., Wagner, P. (Eds.), Transnational Intellectual Networks. Campus, Frankfurt, pp. 401-450.

Charle, C., 2004b. Patterns. In: Rüegg, W. (Ed.), A History of the University in Europe: Volume III: Universities in the Nineteenth and Early Twentieth Centuries (1800-1945). Cambridge University Press, Cambridge, pp. 33-80.

Cochrane, A., Williams, R., 2012. Putting higher education in its place: the socio-political geographies of English universities. Policy \& Politics, fast track article http://www.ingentaconnect.com/content/tpp/pap/preprints/15784.

Deem, R., Mok, K.H., Lucas, L., 2008. Transforming higher education in whose image? Exploring the concept of the 'world-class' university in Europe and Asia. Higher Education Policy 21 (1), 83-97. 
Dill, D.D., Soo, M., 2005. Academic quality, league tables, and public policy: a cross-national analysis of university ranking systems. Higher Education 49 (4), 495-533.

Enserink, M., 2007. Who ranks the university rankers? Science 317, 1026-1028.

Epstein, D., Boden, R., Deem, R., Rizvi, F., Wright, S. (Eds.), 2007. Geographies of Knowledge, Geometries of Power: Framing the Future of Higher Education. World Yearbook of Education 2008. Routledge, New York.

Espeland, W.N., Sauder, M., 2007. Ranking and reactivity: how public measures recreate social worlds. American Journal of Sociology 113 (1), $1-40$.

Faulconbridge, J.R., Hall, S., 2009. Educating professionals and professional education in a geographical context. Geography Compass 3 (1), 171-189.

Findlay, A., King, R., Stam, A., Ruiz-Gelices, E., 2006. Ever reluctant Europeans: the changing geographies of UK students studying and working abroad. European Urban and Regional Studies 13 (4), 291-318.

Findlay, A., King, R., Smith, F.M., Geddes, A., Skeldon, R., 2012. World class? An investigation of globalisation, difference and international student mobility. Transactions of the Institute of British Geographers 37 (1), 118131.

Florian, R.V., 2007. Irreproducibility of the results of the Shanghai ranking of world universities. Scientometrics 72 (1), 25-32. 
Garcia-Ramon, M., 2003. Globalization and international geography: the questions of languages and scholarly traditions. Progress in Human Geography 27 (1), 1-5.

Goddard, J., Vallance, P., 2011. Universities and regional development. In: Pike, A., Rodríguez-Pose, A., Tomaney, J. (Eds.), Handbook of Local and Regional Development. Routledge, London, pp. 425-437.

Hall, S., 2008. Geographies of business education: MBA programmes, reflexive business schools and the cultural circuit of capital. Transactions of the Institute of British Geographers 33 (1), 27-41.

Halpin, T., Buckley, C., 2004. Forget oil, overseas students make money. The Times 23 April 2004.

Hannah, M.G., 2011. Audit cultures in academia. EspacesTemps.net, Actuel, 31.01.2011 http://espacestemps.net/document8550.html (accessed 24.09.12).

Hanson Thiem, C., 2009. Thinking through education: the geographies of contemporary educational restructuring. Progress in Human Geography 33 (2), 154-173.

Haraway, D., 1988. Situated knowledges: the science question in feminism and the privilege of partial perspective. Feminist Studies 14 (3), 575-599.

Hazelkorn, E., 2011. Rankings and the Reshaping of Higher Education: The Battle for World-Class Excellence. Palgrave Macmillan, Basingstoke.

Hazen, H.D., Alberts, H.C., 2006. Visitors or immigrants? International students in the United States. Population, Space and Place 12 (3), 201-216. 
HEFCE, 2008. Counting What is Measured or Measuring What Counts? League Tables and their Impact on Higher Education Institutions in England. CHERI, Open University, and Hobsons Research, HEFCE, Bristol http://www.hefce.ac.uk/pubs/hefce/2008/08_14/ (accessed 08.10.11).

Heffernan, M., Jöns, H., 2007. Degrees of influence: the politics of honorary degrees in the Universities of Oxford and Cambridge, 1900-2000. Minerva 45 (4), 389-416.

Helms, G., Lossau, J., Oslender, U., 2005. Einfach sprachlos but not simply speechless: language(s), thought and practice in the social sciences. Area 37 (3), $242-250$.

Holloway, S.L., Jöns, H., 2012. Geographies of education and learning. Transactions of the Institute of British Geographers 37 (4), 482-488.

Holloway, S.L., Hubbard, P., Jöns, H., Pilmott-Wilson, H., 2010. Geographies of education and the significance of children, youth and families. Progress in Human Geography 34 (5), 583-600.

Holmes, R., 2006. The THES university rankings: are they really world class? Asian Journal of University Education 2 (1), 1-14.

Hoyler, M., Jöns, H., 2008. Global knowledge nodes and networks. In: Johnson, C., Hu, R., Abedin, S. (Eds.), Connecting Cities: Networks. Metropolis Congress, Sydney, pp. 124-151.

Huisman, J., 2008. World-class universities. Higher Education Policy 21 (1), 14.

IAU, 2008. World Higher Education Database: CD Rom Version. Palgrave Macmillan, Basingstoke. 
IAU, 2010. World Higher Education Database: CD Rom Version. Palgrave Macmillan, Basingstoke.

IHEP, 2009. Impact of College Rankings on Institutional Decision Making: Four Country Case Studies. Institute for Higher Education Policy, Washington D.C.

IREG, 2006. Berlin Principles on Ranking of Higher Education Institutions. CHE University Ranking, UNESCO-CEPES \& Institute for Higher Education Policy, Berlin http://www.che.de/downloads/Berlin_Principles_IREG_534.pdf (accessed 08.10.11).

Jöns, H., 2007. Transnational mobility and the spaces of knowledge production: a comparison of global patterns, motivations and collaborations in different academic fields. Social Geography 2, 97-114.

Jöns, H., 2008. Academic travel from Cambridge University and the formation of centres of knowledge, 1885-1954. Journal of Historical Geography 34 (2), 338-362.

Jöns, H., 2009. 'Brain circulation' and transnational knowledge networks: studying long-term effects of academic mobility to Germany, 1954-2000. Global Networks 9 (3), 315-338.

Kaur, S., 2007. Global university rankings 2007: interview with Simon $\begin{array}{llll}\text { Marginson. } & \text { GlobalHigherEd } & 12 & \text { December }\end{array}$ http://globalhighered.wordpress.com/2007/12/12/global-universityrankings-2007-interview-with-simon-marginson/ (accessed 08.10.11). 
Kenway, J., Bullen, E., Robb, S., 2004. The knowledge economy, the technopreneur and the problematic future of the university. Policy Futures in Education 2 (2), 330-349.

Kenway, J., Bullen, E., Fahey, J., Robb, S., 2006. Haunting the Knowledge Economy. Routledge, London.

Kitchin, R., 2005. Commentary: disrupting and destabilizing Anglo-American and English-language hegemony in geography. Social and Cultural Geography 6 (1), 1-15.

Kivinen, O. and Hedman, J., 2008. World-wide university rankings: a Scandinavian approach. Scientometrics 74 (3), 391-408.

Knight, J., 2003. Internationalization of Higher Education: Practices and Priorities: IAU Survey Report. International Association of Universities, Paris

http://www.unesco.org/iau/internationalization/pdf/Internationalisationen.pdf (accessed 08.10.11).

Lai, A., Maclean, R., 2011. Managing human capital in world cities: the development of Hong Kong into an education hub. Asia Pacific Journal of Education 31 (3), 249-262.

Lawton Smith, H., 2006. Universities, Innovation and the Economy. Routledge, London.

Leung, M., 2011. Of corridors and chains: translocal developmental impacts of academic mobility between China and Germany. International Development Planning Review 33 (4), 475-489. 
Levin, R.C., 2010. The rise of Asia's universities. The New York Times 21 April 2010 http://www.nytimes.com/2010/04/21/opinion/21iht-edlevin.html (accessed 08.10.11).

Leydesdorff, L., Wagner, C.S., 2009a. Is the United States losing ground in science? A global perspective on the world science system. Scientometrics 78 (1), 23-36.

Leydesdorff, L., Wagner, C., 2009b. Macro-level indicators of the relations between research funding and research output. Journal of Informetrics 3 (4), 353-362.

Liu, N.C., 2009. The story of academic rankings. International Higher Education (54), 2-3 http://www.bc.edu/research/cihe/ihe.html (accessed 08.10.11).

Liu, N.C., Cheng, Y., 2005. The academic ranking of world universities. Higher Education in Europe 30 (2), 127-136.

Liu, N.C., Liu, L., 2005. University rankings in China. Higher Education in Europe 30 (2), 217-227.

Livingstone, D.N., 2003. Putting Science in its Place: Geographies of Scientific Knowledge. The University of Chicago Press, Chicago.

Lynch, K., 2006. Neo-liberalism and marketisation: the implications for higher education. European Educational Research Journal 5 (1), 1-17.

Marginson, S., 2006. Dynamics of national and global competition in higher education. Higher Education 52 (1), 1-39.

Marginson, S., 2007. Global university rankings: implications in general and for Australia. Journal of Higher Education Policy and Management 29 (2), $131-142$. 
Marginson, S., van der Wende, M., 2007. To rank or to be ranked: the impact of global rankings in higher education. Journal of Studies in International Education 11 (3-4), 306-329.

Marshall, J., 2007. French reform plans on hold. Times Higher Education 6 July 2007 http://www.timeshighereducation.co.uk/story.asp?storyCode=209555 (accessed 08.10.11).

Massey, D., 1999. Power-geometries and the Politics of Space-time. University of Heidelberg, Heidelberg.

Matthiessen, C.W., Schwarz, A.W., Find, S., 2010. World cities of scientific knowledge: systems, networks and potential dynamics. An analysis based on bibliometric indicators. Urban Studies 47 (9), 1879-1897.

Meusburger, M., Schuch, T. (Eds.), 2012. Wissenschaftsatlas of Heidelberg University. Bibliotheca Palatina, Knittlingen.

Minca, C., 2000. Venetian geographical practice. Environment and Planning D: Society and Space 18 (3), 285-289.

Mitchell, D., 2008. The insidious work of the university: from nationalism to excellence to entrepreneurialism. Human Geography 1 http://www.hugeog.com/free/078_Mitchell_I1N1.pdf (accessed 08.10.11).

Moed, H.F., 2006. Bibliometric Rankings of World Universities. Centre for Science and Technology Studies, Leiden University.

Morgan, J., 2010. OECD may fill 'missing link' in world university rankings $\begin{array}{lllll}\text { Times } & \text { Higher } & \text { Education } & 1 & \text { February }\end{array}$ http://www.timeshighereducation.co.uk/story.asp?storycode=410212 (accessed 08.10.11). 
NSF (Ed.), 2009. Doctorate Recipients from U.S. Universities: Summary Report 2007-08. National Science Foundation, Arlington.

O'Connor, K., 2005. International Students and Global Cities. GaWC Research Bulletin 161 http://www.lboro.ac.uk/gawc/rb/rb161.html (accessed 08.10.11).

OECD (Ed.), 2009. Education at a Glance 2009. OECD, Paris.

OECD (Ed.), 2012. Education at a Glance 2012. OECD, Paris.

Olds, K., 2007a. Global assemblage: Singapore, foreign universities, and the construction of a 'global education hub'. World Development 35 (6), 959975.

Olds, K., 2007b. University rankings: deliberations and future directions. $\begin{array}{llll}\text { GlobalHigherEd } & 19 & \text { November } & 2007\end{array}$ http://globalhighered.wordpress.com/2007/11/19/university-rankingsdeliberations-and-future-directions/ (accessed 08.10.11).

Olds, K., 2008. New 2008 Shanghai rankings, by rankers who also certify $\begin{array}{lllll}\text { rankers. } & \text { GlobalHigherEd } & 7 & \text { August } & 2008\end{array}$ http://globalhighered.wordpress.com/2008/08/07/new-2008-shanghairankings/ (accessed 08.10.11).

Olds, K., Robertson, S. (Eds.), 2007. GlobalHigherEd: Surveying the Construction of Global Knowledge/Spaces for the 'Knowledge Economy'. http://globalhighered.wordpress.com (accessed 08.10.11).

Olds, K., Robertson, S., 2008. Education cities, knowledge villages, schoolhouses, education hubs, and hotspots: emerging metaphors for $\begin{array}{lllll}\text { global higher ed. GlobalHigherEd } 16 & \text { April } 2008\end{array}$ 
http://globalhighered.wordpress.com/2008/04/16/metaphors/ (accessed 08.10.11).

Paasi, A., 2005. Globalisation, academic capitalism, and the uneven geographies of international journal publishing spaces. Environment and Planning A 37 (5), 769-789.

Pietsch, T., 2010. Wandering scholars? Academic mobility and the British World, 1850-1940. Journal of Historical Geography 36 (4), 377-387.

QS Quacquarelli Symonds Limited, 2010. World University Rankings. http://www.topuniversities.com/university-rankings (accessed 08.10.11).

Rauhvargers, A., 2011. Global University Rankings and their Impact. European University Association, Brussels.

Robertson, S. and Olds, K., 2010. Étude de la mondialisation des classements universitaires: projets, programmes et transformations socials. Revue international d'éducation 54 (Septembre 2010), 105-116.

Rodríguez-Pose, A., 2006. Is there an 'Anglo-American' domination in human geography? And, is it bad? Environment and Planning A 38 (4), 603-610.

Rutten, R., Boekema, F., Kuijpers, E. (Eds.), 2003. Economic Geography of Higher Education: Knowledge Infrastructure and Learning Regions. Routledge, New York.

Sadlak, S., Liu, N.C. (Eds.), 2007. The World-class University and Ranking: Aiming beyond Status. UNESCO-CEPES, Bucharest.

Samers, M., Sidaway, J.D., 2000. Exclusions, inclusions, and occlusions in 'Anglo-American geography': reflections on Minca's "Venetian 
geographical practice". Environment and Planning D: Society and Space 18 (6), 663-666.

Saxenian, A., 2006. The New Argonauts: Regional Advantage in a Global Economy. Harvard University Press, Cambridge, MA.

ShanghaiRanking Consultancy, 2010. Academic Ranking of World Universities. http://www.arwu.org/ (accessed 08.10.11).

Smith, D.P., Holt, L., 2007. Studentification and 'apprentice' gentrifiers within Britain's provincial towns and cities: extending the meaning of gentrification? Environment and Planning A 39 (1), 142-161.

Steinberg, P.E., 2009. Internationalism, hegemony, community, and the megaconference: a response to Lawrence Berg. ACME 8 (3), 552-558.

Strathern, M. (Ed.) 2000. Audit Cultures. Routledge, London.

Taylor, P., Braddock, R., 2007. International university ranking systems and the idea of university excellence. Journal of Higher Education Policy and Management 29 (3), 245-260.

Taylor, P.J., 1996. The Way the Modern World Works: World Hegemony to World Impasse. John Wiley, Chichester.

Taylor, P.J., Hoyler, M., Evans, D.M., 2008. A geohistorical study of 'the rise of modern science': mapping scientific practice through urban networks. Minerva 46 (4), 391-410.

Teichler, U., 2004. The changing debate on internationalization of higher education. Higher Education 48 (1), 5-26.

Théry, H., 2009. Palmarès des universités mondiales, «Shanghai» et les autres. M@ppemonde 
http://mappemonde.mgm.fr/num24/articles/art09401.html

(accessed 08.10.11).

U.S.

News

(Ed.),

2010.

Rankings.

http://www.usnews.com/sections/rankings/index.html (accessed 08.10.11).

Universities UK (Ed.), 2007. Talent Wars: The International Market for Academic Staff. Universities UK, London

Usher, A., Savino, M., 2006. A World of Difference: A Global Survey of University League Tables. Educational Policy Institute, Toronto.

Van Raan, A.F.J., 2005. Fatal attraction: conceptual and methodological problems in the ranking of universities by bibliometric methods. Scientometrics 62 (1), 133-143.

Van Raan, A.F.J., van Leeuwen, T.N., Visser, M.S., 2011. Severe language effect in university rankings: particularly Germany and France are wronged in citation-based rankings. Scientometrics 88 (2), 495-498.

Van Vught, F., Ziegele, F. (Eds.) 2011. U-Multirank. Design and Testing the Feasibility of a Multidimensional Global University Ranking. CHERPA Network http://ec.europa.eu/education/highereducation/doc/multirank_en.pdf (accessed 08.10.11).

Waters, J.L., 2012. The socio-spatial fragmentation of higher education: some unexpected consequences of internationalisation. Geoforum 43 (5), A1A3.

Yonezawa, A., 2007. Japanese flagship universities at a crossroads. Higher Education 54 (4), 483-499. 


\section{Tables}

Table 1 Composition of the Shanghai and THE-QS rankings 2009

\begin{tabular}{|c|c|c|c|c|}
\hline \\
\hline \multirow{2}{*}{ Topic } & \multicolumn{2}{|l|}{ A. Shanghai ranking } & \multicolumn{2}{|l|}{ B. THE-QS ranking } \\
\hline & Indicator & $\%$ & Indicator & $\%$ \\
\hline A.1/B.1 & 1. Nobel Prizes \& Fields & 10 & 1. Staff/student score & 20 \\
\hline Quality of education & $\begin{array}{l}\text { Medals of alumni } \\
\text { 1901-2008 }\end{array}$ & & Date not available & \\
\hline A.2-3 & 2. Nobel Prizes \& Fields & 20 & 2. Recruiter review score & 10 \\
\hline $\begin{array}{l}\text { Quality of faculty } \\
\text { B.2-3 }\end{array}$ & $\begin{array}{l}\text { Medals of researchers } \\
\text { 1911-2008 }\end{array}$ & & $2007-09(n=3281)$ & \\
\hline \multirow[t]{4}{*}{ Reputation } & 3. Highly cited researchers & 20 & 3. Peer review score & 40 \\
\hline & (21 SET/social sc. fields) & & $2007-09(n=9386)$ & \\
\hline & Thomson ISI & & & \\
\hline & Date not available & & & \\
\hline \multirow{4}{*}{$\begin{array}{l}\text { A.4-5/B.4 } \\
\text { Research output }\end{array}$} & 4. Articles published in & 20 & 4. Citations/FTE staff score & 20 \\
\hline & $\begin{array}{l}\text { Nature \& Science } \\
\text { 2004-08 }\end{array}$ & & Scopus 2004-08 & \\
\hline & 5. Articles published in & 20 & & \\
\hline & $\begin{array}{l}\text { Web of Science (SCI- } \\
\text { expanded \& SSCl) } 2008\end{array}$ & & & \\
\hline \multirow{3}{*}{$\begin{array}{l}\text { A.6 } \\
\text { Size of institution } \\
\text { B.5-6 } \\
\text { International outlook }\end{array}$} & 6. Academic performance & 10 & 5. International faculty & 5 \\
\hline & $\begin{array}{l}\text { ( } 5 \text { indicators above) by } \\
\text { FTE academic staff }\end{array}$ & & score Date not available & \\
\hline & & & $\begin{array}{l}\text { 6. International students } \\
\text { score Date not available }\end{array}$ & 5 \\
\hline
\end{tabular}

Source: ShanghaiRanking Consultancy (2010); QS Quacquarelli Symonds Limited (2010). 
Table 2 Overlap between the Shanghai and the THE-QS rankings 2006 and 2009

(a) 2006

\begin{tabular}{lrcrrrr}
\hline Universities in & $\mathrm{N}$ & $\begin{array}{c}\text { Top } 100 \\
\% \text { of }\end{array}$ & $\begin{array}{c}\text { \% of } \\
100\end{array}$ & $\mathrm{~N}$ & $\begin{array}{c}\text { Top } 200 \\
\% \text { of } \\
N\end{array}$ & $\begin{array}{c}\text { \% of } \\
200\end{array}$ \\
\hline Both rankings & 60 & 43 & 60 & 136 & 52 & 68 \\
Only Shanghai & 41 & 29 & 41 & 64 & 24 & 32 \\
Only THE-QS & 40 & 28 & 40 & 64 & 24 & 32 \\
Total & 141 & & & 264 & & \\
\hline
\end{tabular}

Source: ShanghaiRanking Consultancy 2010; QS Quacquarelli Symonds Limited 2010; own calculations.

(b) 2009

\begin{tabular}{|c|c|c|c|c|c|c|c|c|c|}
\hline \multirow{2}{*}{ Universities in } & \multicolumn{3}{|c|}{ Top 100} & \multicolumn{3}{|c|}{ Top 200} & \multicolumn{3}{|c|}{ Top 300} \\
\hline & $\mathrm{N}$ & $\begin{array}{c}\% \text { of } \\
N\end{array}$ & $\begin{array}{c}\% \text { of } \\
100\end{array}$ & $\mathrm{~N}$ & $\begin{array}{c}\% \text { of } \\
N\end{array}$ & $\begin{array}{c}\% \text { of } \\
200\end{array}$ & $\mathrm{~N}$ & $\begin{array}{c}\% \text { of } \\
N\end{array}$ & $\begin{array}{c}\% \text { of } \\
300\end{array}$ \\
\hline Both rankings & 63 & 46 & 63 & 138 & 53 & 69 & 223 & 59 & 74 \\
\hline Only Shanghai & 37 & 27 & 37 & 62 & 24 & 31 & 79 & 21 & 26 \\
\hline Only THE-QS & 37 & 27 & 37 & 62 & 24 & 31 & 77 & 20 & 26 \\
\hline Total & 137 & & & 262 & & & 379 & & \\
\hline
\end{tabular}

\begin{tabular}{lcccccc}
\hline Universities in & $\mathrm{N}$ & $\begin{array}{c}\text { Top } 400 \\
\% \text { of } \\
N\end{array}$ & $\begin{array}{c}\text { \% of } \\
400\end{array}$ & $\mathrm{~N}$ & $\begin{array}{c}\text { Top } 500 \\
\% \text { of } \\
N\end{array}$ & $\begin{array}{c}\text { \% of } \\
500\end{array}$ \\
\hline Both rankings & 299 & 60 & 75 & 381 & 61 & 76 \\
Only Shanghai & 102 & 20 & 26 & 120 & 19 & 24 \\
Only THE-QS & 101 & 20 & 25 & 119 & 19 & 24 \\
Total & 502 & & & 620 & & \\
\hline
\end{tabular}

Source: ShanghaiRanking Consultancy 2010; QS Quacquarelli Symonds Limited 2010; own calculations. 
Table 3 Share of 'world-class' universities by country 2006 and 2009

\begin{tabular}{lrrrrrrrr}
\hline Country & \multicolumn{4}{c}{ Shanghai ranking } & \multicolumn{5}{c}{ THE-QS ranking } \\
& \multicolumn{1}{c}{ Top 200 (in \%) } & Top 500 (in \%) & Top 200 (in \%) & Top 500 (in \%) \\
& 2006 & \multicolumn{1}{c}{2009} & 2006 & 2009 & 2006 & 2009 & 2006 & 2009 \\
\hline United States & 43.5 & 45.0 & 33.4 & 30.3 & 27.5 & 27.0 & n.a. & 20.8 \\
Japan & 4.5 & 4.5 & 6.4 & 6.2 & 5.5 & 5.5 & n.a. & 6.4 \\
Russian Federation & 0.5 & 0.5 & 0.4 & 0.4 & 1.0 & 1.0 & n.a. & 0.8 \\
India & 0.0 & 0.0 & 0.4 & 0.4 & 1.5 & 1.0 & n.a. & 2.0 \\
China & 0.5 & 0.0 & 1.0 & 3.6 & 3.0 & 3.0 & n.a. & 2.2 \\
United Kingdom & 11.0 & 11.5 & 8.6 & 8.0 & 14.5 & 14.5 & n.a. & 10.2 \\
France & 3.0 & 3.5 & 4.2 & 4.6 & 3.5 & 2.0 & n.a. & 4.2 \\
Brazil & 0.5 & 0.5 & 0.8 & 1.2 & 0.0 & 0.0 & n.a. & 0.8 \\
Germany & 7.5 & 7.0 & 8.0 & 8.0 & 5.0 & 5.0 & n.a. & 8.2 \\
Canada & 4.0 & 3.0 & 4.4 & 4.4 & 3.5 & 5.5 & n.a. & 4.0 \\
Australia & 3.0 & 3.0 & 3.2 & 3.4 & 6.5 & 4.5 & n.a. & 4.8 \\
South Africa & 0.0 & 0.0 & 0.8 & 0.6 & 0.0 & 0.5 & n.a. & 0.6 \\
Sweden & 2.0 & 2.0 & 2.2 & 2.2 & 2.0 & 2.5 & n.a. & 1.8 \\
Netherlands & 3.5 & 4.5 & 2.4 & 2.4 & 5.5 & 5.5 & n.a. & 2.4 \\
Switzerland & 3.0 & 3.0 & 1.6 & 1.6 & 3.5 & 3.5 & n.a. & 1.6 \\
\hline Source: ShanghaiRanking Consultancy 2010; QS Quacquarelli Symonds Limited 2010; \\
own calculations.
\end{tabular}


Table 4 Share of 'world-class' universities in per cent of doctorate-granting institutions 2009

(a) Shanghai ranking

\begin{tabular}{|c|c|c|c|c|c|c|}
\hline \multirow[t]{2}{*}{ Country } & \multirow{2}{*}{$\begin{array}{c}{ }^{*} \text { All } \\
\text { doctorate- } \\
\text { granting } \\
\text { universities } \\
N\end{array}$} & \multicolumn{5}{|c|}{$\begin{array}{l}{ }^{* * *} \text { Universities ranked in the Shanghai ranking } 2009 \\
\text { (in \% of all doctorate-granting universities) }\end{array}$} \\
\hline & & Top 100 & Top 200 & Top 300 & Top 400 & Top 500 \\
\hline United States & ${ }^{* *} 421$ & 13.1 & 21.4 & 26.6 & 32.8 & 35.6 \\
\hline Japan & 347 & 1.4 & 2.6 & 3.2 & 5.5 & 8.4 \\
\hline Russian Federation & 270 & 0.4 & 0.4 & 0.4 & 0.7 & 0.7 \\
\hline India & 246 & 0.0 & 0.0 & 0.0 & 0.4 & 0.8 \\
\hline China & 222 & 0.0 & 0.0 & 2.7 & 3.6 & 6.8 \\
\hline United Kingdom & 148 & 7.4 & 15.5 & 22.3 & 24.3 & 25.7 \\
\hline France & 147 & 2.0 & 4.8 & 9.5 & 12.9 & 13.6 \\
\hline Brazil & 113 & 0.0 & 0.9 & 1.8 & 3.5 & 4.4 \\
\hline Germany & 94 & 5.3 & 14.9 & 25.5 & 38.3 & 40.4 \\
\hline Canada & 57 & 7.0 & 10.5 & 31.6 & 31.6 & 33.3 \\
\hline Australia & 43 & 7.0 & 14.0 & 20.9 & 30.2 & 34.9 \\
\hline South Africa & 24 & 0.0 & 0.0 & 4.2 & 8.3 & 12.5 \\
\hline Sweden & 17 & 17.6 & 23.5 & 41.2 & 52.9 & 64.7 \\
\hline Netherlands & 13 & 15.4 & 69.2 & 69.2 & 84.6 & 92.3 \\
\hline Switzerland & 12 & 25.0 & 50.0 & 58.3 & 58.3 & 66.7 \\
\hline
\end{tabular}

Sources: * IAU (2008); ${ }^{* *}$ NSF (2009); ${ }^{* * *}$ ShanghaiRanking Consultancy (2010); own calculations.

(b) THE-QS ranking

\begin{tabular}{|c|c|c|c|c|c|c|}
\hline \multirow[t]{2}{*}{ Country } & \multirow{2}{*}{$\begin{array}{c}{ }^{*} \text { All } \\
\text { doctorate- } \\
\text { granting } \\
\text { universities } \\
N\end{array}$} & \multicolumn{5}{|c|}{$\begin{array}{l}{ }^{* * *} \text { Universities ranked in the THE-QS ranking } 2009 \\
\text { (in \% of all doctorate-granting universities) }\end{array}$} \\
\hline & & Top 100 & Top 200 & Top 300 & Top 400 & Top 500 \\
\hline United States & ${ }^{* *} 421$ & 7.6 & 12.8 & 16.6 & 20.7 & 24.7 \\
\hline Japan & 347 & 1.7 & 3.2 & 3.7 & 5.5 & 9.2 \\
\hline Russian Federation & 270 & 0.0 & 0.7 & 0.7 & 1.1 & 1.5 \\
\hline India & 246 & 0.0 & 0.8 & 2.0 & 2.4 & 4.1 \\
\hline China & 222 & 0.9 & 2.7 & 3.2 & 3.2 & 5.0 \\
\hline United Kingdom & 148 & 12.2 & 19.6 & 25.7 & 31.8 & 34.5 \\
\hline France & 147 & 1.4 & 2.7 & 8.8 & 11.6 & 14.3 \\
\hline Brazil & 113 & 0.0 & 0.0 & 1.8 & 2.7 & 3.5 \\
\hline Germany & 94 & 4.3 & 10.6 & 20.2 & 34.0 & 43.6 \\
\hline Canada & 57 & 7.0 & 19.3 & 28.1 & 33.3 & 35.1 \\
\hline Australia & 43 & 18.6 & 20.9 & 44.2 & 51.2 & 55.8 \\
\hline South Africa & 24 & 0.0 & 4.2 & 4.2 & 8.3 & 12.5 \\
\hline Sweden & 17 & 11.8 & 29.4 & 41.2 & 47.1 & 52.9 \\
\hline Netherlands & 13 & 30.8 & 84.6 & 92.3 & 92.3 & 92.3 \\
\hline Switzerland & 12 & 33.3 & 58.3 & 58.3 & 66.7 & 66.7 \\
\hline
\end{tabular}

Source: * IAU (2008); **NSF (2009); ${ }^{* * *}$ QS Quacquarelli Symonds Limited (2010); own

calculations. 
Table 5 Top 10 cities in the Shanghai and THE-QS rankings 2009

\begin{tabular}{|c|c|c|c|}
\hline \multirow{3}{*}{$\begin{array}{l}\text { City } \\
\text { London }\end{array}$} & \multirow{3}{*}{$\begin{array}{l}\text { Country } \\
\text { UK }\end{array}$} & \multicolumn{2}{|c|}{ Number of institutions among Top 500 (highest rank) } \\
\hline & & Shanghai ranking & THE-QS ranking \\
\hline & & $9(21)$ & $11 \quad(4)$ \\
\hline Paris & France & $9 \quad(40)$ & $11 \quad(28)$ \\
\hline Tokyo & Japan & $7 \quad$ (20) & (22) \\
\hline New York & USA & $7 \quad(7)$ & (11) \\
\hline Seoul & South Korea & 5 (101) & $8 \quad(47)$ \\
\hline Hong Kong & China & 5 (201) & $6 \quad(24)$ \\
\hline Houston & USA & $5 \quad$ (99) & $2(100)$ \\
\hline Melbourne & Australia & $4 \quad(75)$ & $5 \quad(36)$ \\
\hline Boston/Cambridge & USA & $4 \quad(1)$ & $4 \quad(1)$ \\
\hline Stockholm & Sweden & $4 \quad(50)$ & 3 (174) \\
\hline Philadelphia & USA & $4 \quad(15)$ & $2 \quad(12)$ \\
\hline Chicago & USA & $3 \quad(9)$ & (7) \\
\hline Sydney & Australia & 3 (94) & (36) \\
\hline Dublin & Ireland & $2(201)$ & $4 \quad(43)$ \\
\hline Buenos Aires & Argentina & 1 (101) & 4 (298) \\
\hline
\end{tabular}




\section{Figures}

Figure 1 Locations of the Top 200 universities in the Shanghai and THE-QS rankings 2009

a. Both rankings

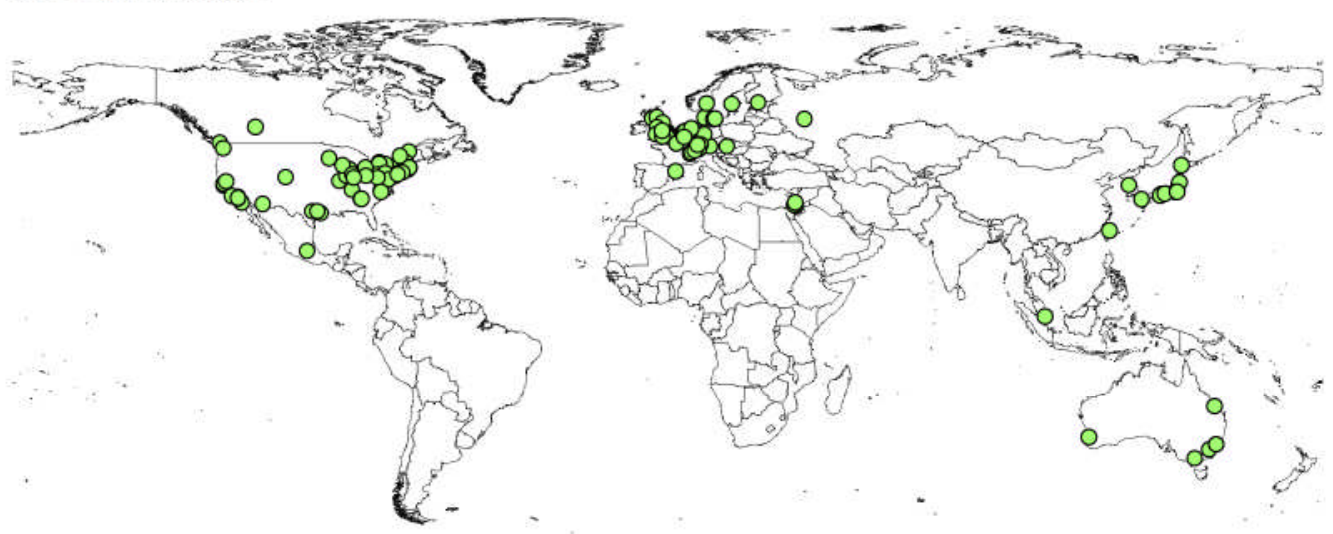

b. Only Shanghai ranking

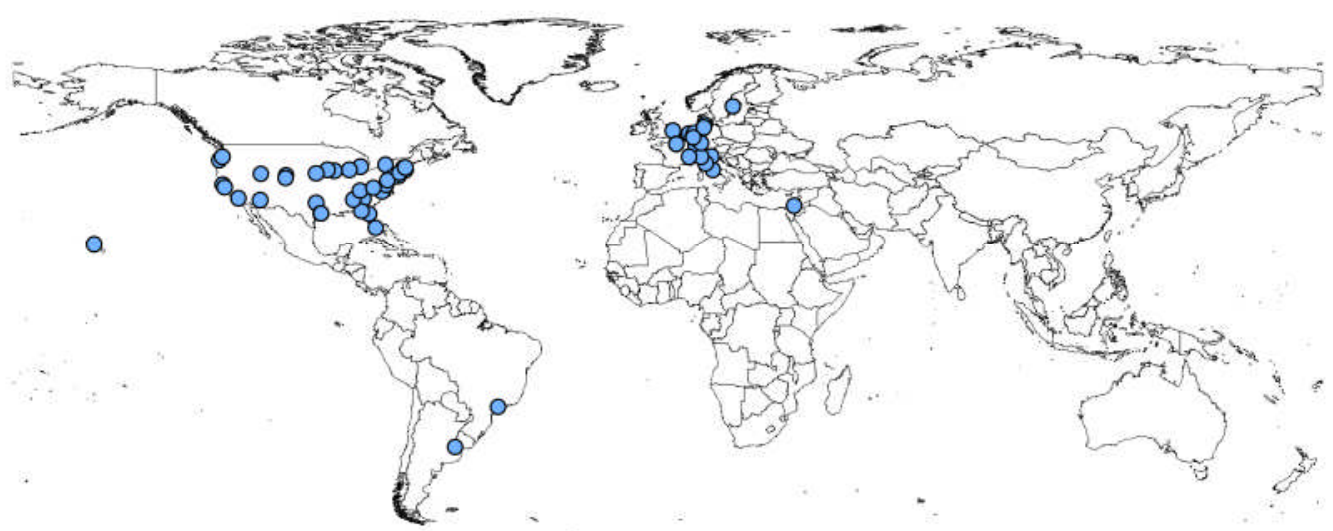

c. Only THE-QS ranking

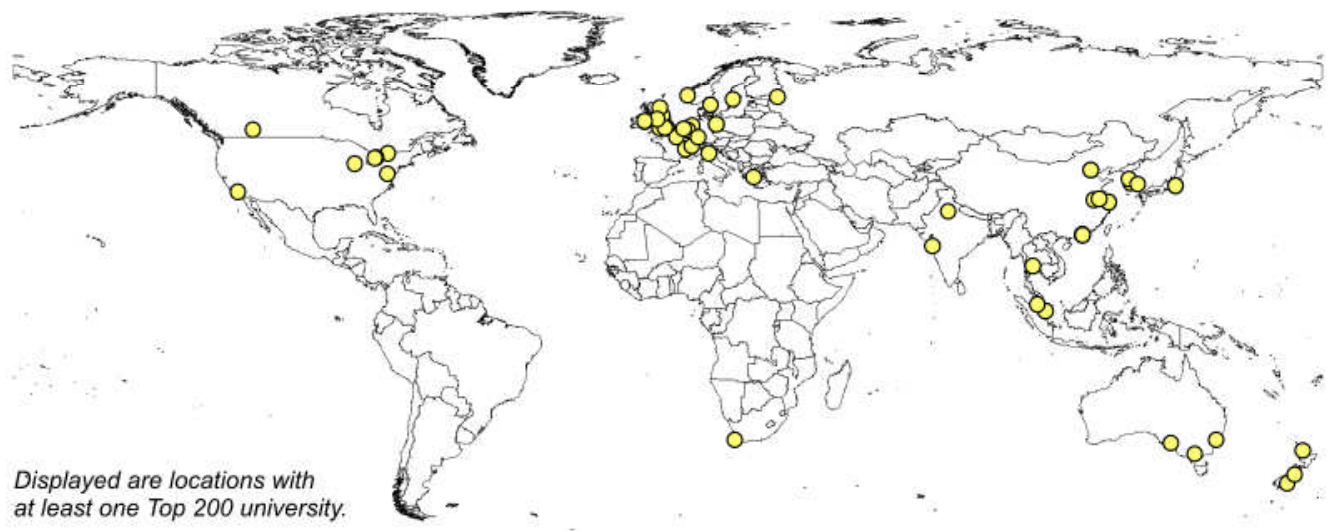

Source: ShanghaiRanking Consultancy (2010); QS Quacquarelli Symonds Limited (2010); own map design. 
Figure 2 Locations of the Top 500 universities in the Shanghai and THE-QS rankings 2009

(a) Shanghai ranking
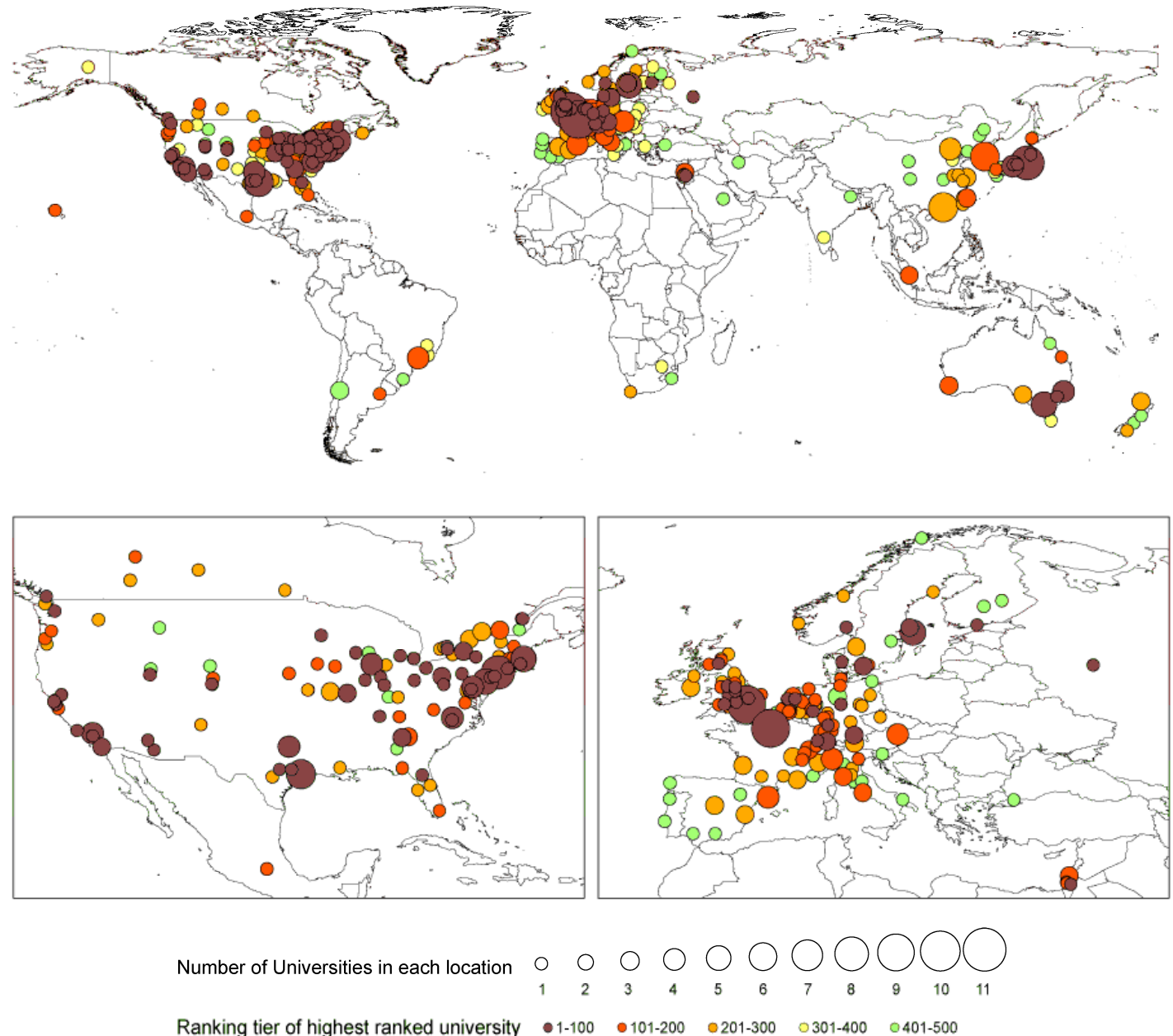
(b) THE-QS ranking
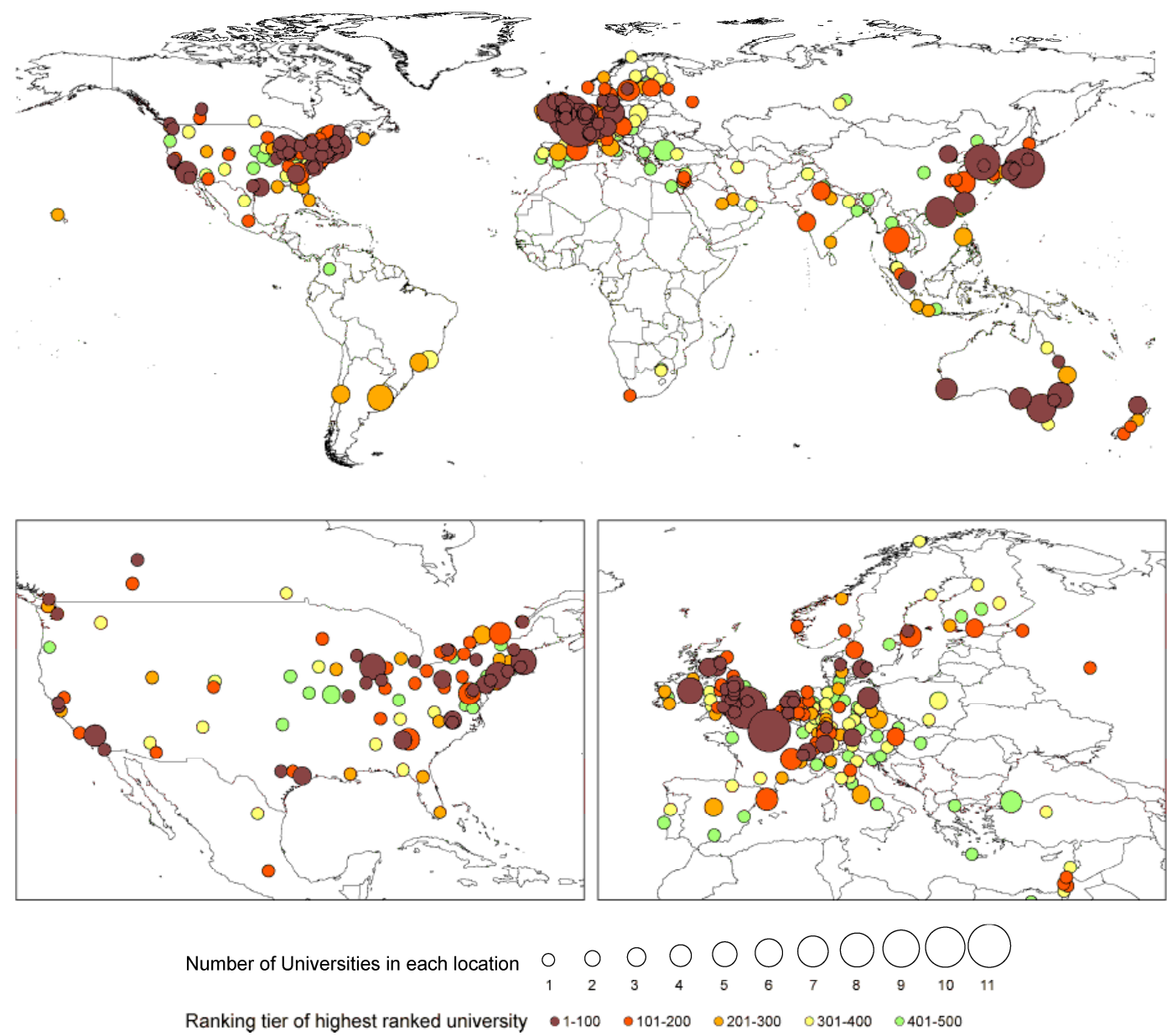

Source: ShanghaiRanking Consultancy (2010); QS Quacquarelli Symonds Limited (2010); own map design. 
Figure 3 Web of Science articles and highly cited scores for the Top 200 institutions in the Shanghai ranking 2009

a. Articles published in Web of Science 2008 (SCl-expanded \& SSCI)

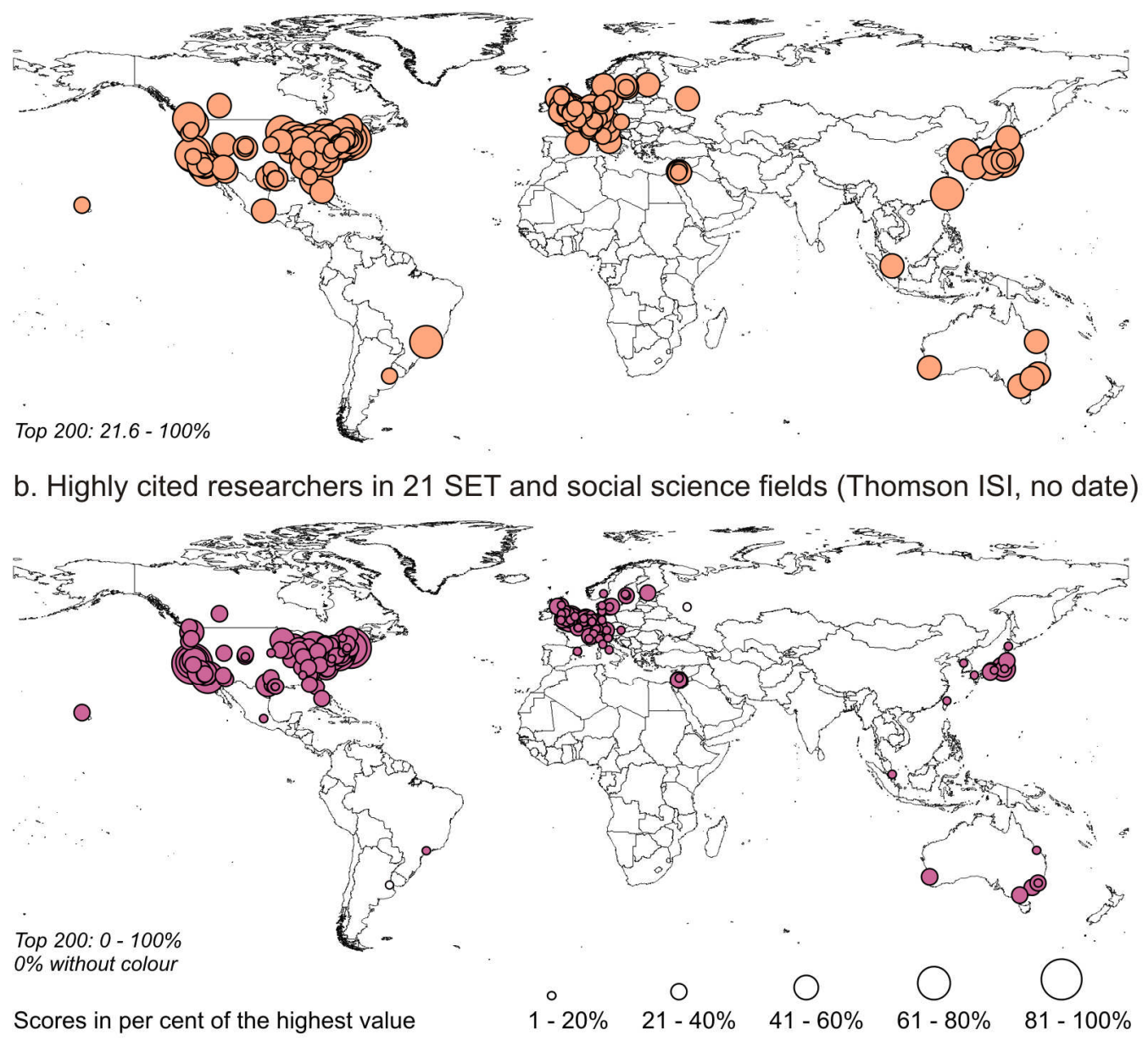

Source: ShanghaiRanking Consultancy (2010); own map design. 
Figure 4 International students at the Top 200 institutions in the THE-QS ranking 2009

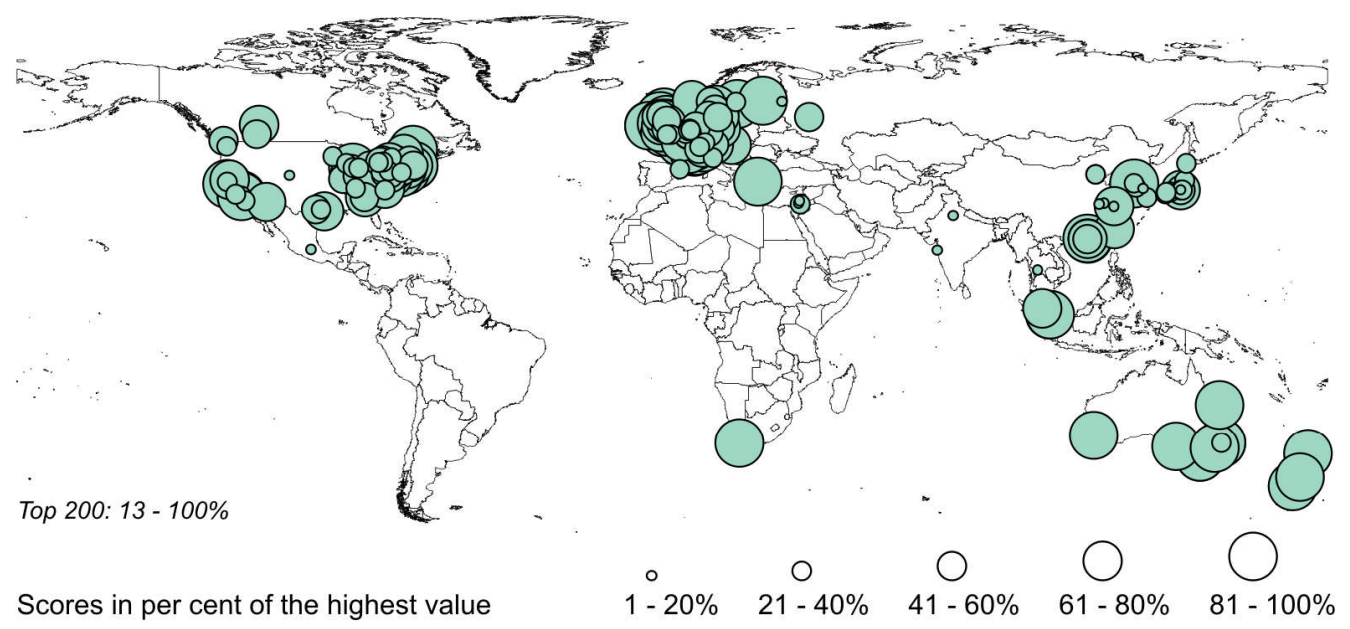

Source: QS Quacquarelli Symonds Limited (2010); own map design. 